\title{
KNIHOVNY ŽENSKÝCH KLÁŠTERŮ V POHUSITSKÉM OBDOBİ
}

\author{
Renáta Modráková (Praha)
}

\author{
Libraries of Female Monasteries in the Post-Hussite Period
}

\begin{abstract}
The libraries of Bohemian female monasteries were distinctive units with thematically diverse codices in both manuscript and printed form. This article focuses on their composition and possible transformation in the Post-Hussite period with an overlap to the 16th century. Five important nunneries of various orders have been chosen as models. These include St George's Benedictine Convent at Prague Castle, the Premonstratensian Convent in Doksany, St Anne's Dominican Convent in the Old Town of Prague, the Premonstratensian Convent in Chotěšov, the Convent of Poor Clares in Český Krumlov and the Convent of Poor Clares in Cheb. The composition and size of a particular library in the period under review depended on the economic, social and cultural situation of each convent. Liturgical books continued to be commissioned, but the number of devotional literature and mystical texts increased. Many monasteries also focused on ordering printed books. The primary aim of the article is to open the whole topic.
\end{abstract}

Keywords: libraries - manuscripts - incunabula - nuns - Premonstratensians - Benedictines - Dominicans - Poor Clares - reform - liturgical books mystical texts

Knihovny ženských klášterů byly svébytné celky s tematicky rozmanitými knihovnami. Jejich velikost i rozmanitost přímo úměrně závisely na významu a ekonomickém a kulturním potenciálu každého konkrétního kláštera. Podobně jako jiné knihovny podléhaly vnějším vlivům, jimiž mohlo být záměrné ničení knižních artefaktů a mnohdy také klášterních budov.

Nosným tématem tohoto prríspěvku bude sledování procesu obnovování klášterních knihoven ženských klášterů pozdně středověkých Čech. Knihovny ženských klášterů měly poněkud odlišnou skladbu titulů oproti knihovnám jejich mužských protějšků. Předně je možné sledovat větší počet liturgických rukopisů pro soukromé účely a s tzv. devoční tematikou. Skladby titulů napříč knihovnami ženských klášterů různých řádů překvapivě až na jedinou výjimku tak rozdílné nebyly. Výrazné rozdíly je možné (opět až na výjimku prezentovanou klášterem klarisek v Chebu) postihnout při srovnání s okolními německými a rakouskými oblastmi, v nichž mnohé kláštery prošly důkladnými reformami. Není primárním cílem tohoto článku podrobněji řešit střet tištěného a rukopisného knižního média - to ostatně nedávno provedl zcela vyčerpávajícím způsobem K. Boldan. ${ }^{1}$ Cílem této studie je především otevření celé problematiky.

\section{Časové určení}

Vymezené časové rozpětí tohoto článku je uvedeno již v samotném titulu. Primární zájem je kladen především na pohusitské období s následným pokračováním do druhé poloviny 15 . století s následným přesahem do šestnáctého století. V úvodních pasážích bude reflektována také situace zvolených knihoven v předcházejících obdobích, zejména během 14. a 15. století. Krátká charakteristika je klíčová zejména pro porovnání situace proměny čtenářstva, knihoven a objednávek textů $\mathrm{v}$ pozdním středověku. $\mathrm{V}$ neposlední řadě byla tato perioda vymezena také pro srovnání situace s kulturně vyspělými ženskými kláštery v německém a rakouském prostoru, které v této době zažívaly značný rozmach.

\section{Zvolené kláštery}

Pro svou studii jsem si vybrala modelové př́íklady knihoven, ze kterých se dochoval knižní materiál ${ }^{2}$ a na jejichž př́kladu je možné vystihnout jednotlivé proudy sledovaného tématu. Jako první to byl klášter benediktinek u svatého Jiří na Pražském hradě, který během své osmisetleté existence vytvořil kompaktní knihovnu a který plně vystihuje kulturní

\footnotetext{
* Př́íspěvek vznikl na základě institucionální podpory dlouhodobého koncepčního rozvoje Národní knihovny ČR jako výzkumné organizace poskytované Ministerstvem kultury ČR (VaV oblast 1 Výzkum knižní kultury středověkých Čech, řešitelem Národní knihovna ČR pro léta 2019-2023)

${ }^{1}$ BOLDAN 2018.

2 Jen v př́ípadě kláštera dominikánek u sv. Anny na Starém Městě pražském ve značně nižším počtu (viz dále).
} 
fenomén kontinuálně působícího bohatého ženského kláštera. Navíc zůstal více méně nedotčený husitskými událostmi a měl dostatečný majetkový kapitál na doplňování nových titulů ve stanoveném období. Dalším sledovaným klášterem je konvent premonstrátek v Doksanech, u kterého bohužel narážíme na jistý nedostatek pramenů pro určené období. Lépe bylo možno podchytit klášter premonstrátek v Chotěšově, který díky svému ekonomickému zázemí disponoval dostatečným množstvím knih. Pro pražské prostředí zmíním také klášter dominikánek u svaté Anny na Starém Městě pražském, který vlastnil zajímavou, i když jen fragmentárně dochovanou knihovnu. Svébytná situace klarisek v Českém Krumlově umožňuje přesný náhled do klášterního společenství, napojeného na mužský klášter. Poslední ze zvolených klášterů, klarisky v Chebu, nejsou uvedeny na závěr jen tak nahodile. Jejich naprosto výjimečná situace prokazuje variabilitu kulturního vývoje pozdně středověkých českých zemí. Zároveň láme mnohé stereotypy, které jsou v prrípadě knihoven ženských klášterů mnohdy předkládány. Zcela stranou ponechávám ty kláštery, jejichž knihovny zcela nebo z drtivé většiny zanikly.

\section{Prameny}

Na úvod je třeba poznamenat, že jsem pracovala se značně omezeným množstvím pramenů. Primárním zdrojem pro můj výzkum byly dochované rukopisy a tisky mnohdy rozeseté v různých současných knihovnách uchovávajících historický materiál. Největší část byla zpracována z historických sbírek Národní knihovny $\breve{C R}^{3}$ a Knihovny Národního muzea. ${ }^{4}$ Pro tento průzkum byly zvoleny knihovny klášterů zrušených během josefinských reforem. Významné porušení původních knihovních celků vedlo k znesnadnění výzkumu. Teprve systematický průzkum proveniencí umožňuje další podrobné studium této problematiky. V současnosti souběžně probíhá zpracování provenienčních poznámek ve středověkých rukopisech a v inkunábulích $\mathrm{z}$ historických sbírek Národní knihovny ČR ${ }^{5}$ a projekt PROVENIO, virtuální rekonstrukce knižních celků, v rámci něhož jsou systematicky zkoumány zejména sbírky tisků Knihovny Národního muzea a Národní knihovny ČR. ${ }^{6}$ Tento příspěvek významně těží průběžné výsledky z obou projektů. Věŕím, že po jejich dokončení bude možné přidat mnoho nového ke sledovanému tématu a zrevidovat dosažené výsledky.

\section{Výzkum ženských klášterních knihoven}

V českém prostředí prozatím zůstává systematický zájem o knihovny ženských klášterů na pozadí nebo lépe řečeno stranou. Výchozí pro mě byla zejména starší práce I. Hlaváčka uvádějící i informace o knihovnách mnohých ženských klášterů. ${ }^{7}$ Výjimkou je v poslední době především práce M. Hradilové, týkající se sice knihovny minoritů v Českém Krumlově, ${ }^{8}$ ale zmiňující mnohé ke klariskám. Méně vyčerpávající, zato podobně klíčová je práce M. Hlinomaze ke knihovně kláštera $v$ Chotěšově a $\mathrm{k}$ dějinám kláštera obecně. ${ }^{9}$ Autorka tohoto článku se systematicky věnuje knihovně benediktinek u svatého Jiří na Pražském hradě. ${ }^{10}$ Výše uvedení autoři se stali hlavními inspirátory tohoto článku a z jejich prací bylo také nejvíce čerpáno. Jinak je tomu $\mathrm{v}$ prrípadě ostatních klášterů. $\mathrm{V}$ případě Doksanského kláštera jsem si musela vypomoci poněkud zastaralou Míkovou prací. ${ }^{11}$ Klášter by si již dávno zasluhoval podrobnější a důkladnější zpracování svých dějin a knihovny. Obdobně zůstala ve stínu zájmu knihovna dominikánek u svaté Anny, ač svým významem hluboce přesahovala pozici prosté lokální knihovny. Podrobnému zpracování prozatím ušly také klarisky v Chebu, i když tam je možné více využít práce věnované klášteru františkánů. $Z$ výstavních počinů jmenujme především katalog k výstavě Žebřik nebeský, ${ }^{12}$ který je skrovným př́spěvkem $\mathrm{k}$ dějinám pozdně středověké knižní kultury.

$\mathrm{V}$ jazykově německém, ${ }^{13}$ francouzském ${ }^{14}$ a anglickém ${ }^{15}$ prostředí byla věnována výzkumu sledovaného tématu podstatně větší pozornost. Tento zájem odborné i široké veřejnosti reflektovalo i několik velkých výstav, které představily ty nejzajímavější knižní památky ženských klášterů na jednom místě (zejména výstavy Krone und Schleier, Rosenkränze, Frauen - Kloster - Kunst). Tyto výstavy byly doprovázeny odbornými publikacemi, které překročily horizont prostých výstavních katalogů. ${ }^{16}$ Zesílený zájem odráži kontinuálně jdoucí literatura, zahájena především klíčovou prací E. Powerové. ${ }^{17}$ Rozsah této drobné práce neumožňuje jmenovat všechny, zastavím se jen u těch, které byly inspirativní pro sledova-

\footnotetext{
${ }^{3}$ TRUHLÁR̆ 1905-1906; TRUHLÁR̆ 1906; DOLCH, 1909; PLOCEK 1973; MAREK - MODRÁKOVÁ 2006; MAREK - DRAGOUN 2016.

${ }^{4}$ BARTOŠ 1926; DRAGOUN 2011; DRAGOUN - MAREK 2012; BRČÁK et al. 2014; BENEŠ et al. 2015; BROM et al. 2016 ; DRAGOUN 2017

${ }^{5} \mathrm{VaV}$ oblast 1 (Výzkum knižní kultury středověkých Čech), řešitelem Národní knihovna ČR pro léta 2019-2023.

${ }^{6}$ Blíže https://www.provenio.net/ [cit. 1. 2. 2020].

${ }^{7}$ HLAVÁČEK 2005.

${ }^{8}$ HRADILOVÁ 2014.

${ }^{9}$ HLINOMAZ 2009

${ }^{10}$ Výběrově MODRÁKOVÁ 2015; MODRÁKOVÁ 2016; MODRÁKOVÁ 2019

${ }^{11}$ MIKA 1726.

${ }^{12}$ STUDNIČKOVÁ - BOLDAN - MODRÁKOVÁ 2019.

${ }^{13}$ EHRENSCHWEDTNER 2004; EISERMANN-SCHLOTHEUBER- HONEMANN 2004; SCHLOTHEUBER 2004; JÄGGI 2006; CARMASSI SCHLOTHEUBER - BREITENBACH 2014

${ }^{14}$ PARISSE 2007.

${ }^{15}$ RENEVEY-WHITEHEAD 2000; ERLER 2002; MULDER-BAKKER 2004; BLANTON - O'MARA - STOOP 2013.

${ }^{16}$ Tady zejména ACHTEN 1980; SIGNORI 2000; HAMBURGER. - JÄGGI - MARTI- RÖCKELEIN 2007; HAMBURGER - MARTI 2008; KRUSE 2013

${ }^{17}$ POWER 2012.
} 
né téma. Začněme v jazykově anglickém prostředí. Zde jsou klíčové práce D. Watt, která se bezprostředně zabývá fenoménem knihoven a autorek jednotlivých děl. ${ }^{18}$ Dále je to práce D. N. Bella, ${ }^{19}$ ze které je v mnohém čerpáno. Z uměleckého hlediska osobně čerpám z prací J. Hamburgera, ${ }^{20}$ jehož práce otevřely knižní umění ženských klášterů především pozdně středověkého období. Značně mi pomohla také práce $\mathrm{S}$. Mengis, ${ }^{21}$ která svojí mikrosondáží do jedné konkrétní knihovny umožnila lépe identifikovat obdobné problémy, s jakými se vypořádáváme při průzkumu českých klášterů. Obdobně byly plně vyčerpány publikace, zabývající se problematikou rekonstrukce středověkých knihoven. ${ }^{22}$

\section{Knihovna kláštera benediktinek u svatého Jiří na Pražském hradě}

Klášter benediktinek u svatého Jiř́i (založen v letech 973 až 976) byl nejstarším klášterem českých zemí vůbec. Již od počátku se podílel na formování kulturní tradice českých zemí (aktivní šíření kultu svaté Ludmily), a to zejména v oblasti hudební tradice, liturgiky a paraliturgické literatury. Po více než osmi stech letech jeho dějin, během nichž si kontinuálně udržel pozici předního českého kláštera, byl v roce 1782 zrušen během josefinských reforem. Jeho knihovna byla přesunuta do nově konstituované knihovny ${ }^{23}$ a dodnes tvoří pozoruhodný rukopisný sbírkový fond, i když rozptýlený mezi ostatními klementinskými rukopisy. V řadě svých prací jsem prokázala, že knihovna tohoto kláštera se řadí mezi přední knihovny evropských ženských benediktinských klášterů. V mnoha př́padech byla ojedinělá a představovala to lepší z kulturní tradice zemí Koruny české.

Tato knihovna představuje svébytnou a kontinuálně vytvářenou knihovnu, doloženou až od druhé poloviny 12. století (nejstarší rukopisy Breviarium NK VI.E.13, Breviarium NK VI.E.4c, Lectionarium NK XII.E.16). Největší rukopisná produkce je sledovatelná zejména pro konec 13. století a celé následující 14. století s mírným přesahem do předhusitského období (Formula novitiam et Regula s. Benedicti, počátek 15. století, NK I.F.29; Psalterium, polovina 13. století, NK I.H.7; Psalterium et hymnarius, 1275-1450, NK VI.G.2; Psalterium et hymnarius, 1250-1400, NK VI.F.12c; Corpus officiorum, 1375-1425, NK VI.G.3a; Processionale, počátek 14. století, NK VI.G.3b; Processionale, 1. polovina 14. století, NK VI.G.5; Processionale, 13./14. století, NK VI.G.10a; Processionale, 14./15. století, NK VI.G.10b; Breviarium, konec 12. století, NK VI.G.1124; Processionale, konec 13. století, NK VI.G.15; Preces pro infirmis, počátek 14. století, NK VI.G.16b; Pseudo-Eusebius: Epistola ad Damasaum et David de Augusta: Speculum monacharum, polovina 14. století, NK VII.D.2; Processionale, 13./14. století, NK VII.G. 7; Processionale, počátek 14. století, NK VII.G.16;

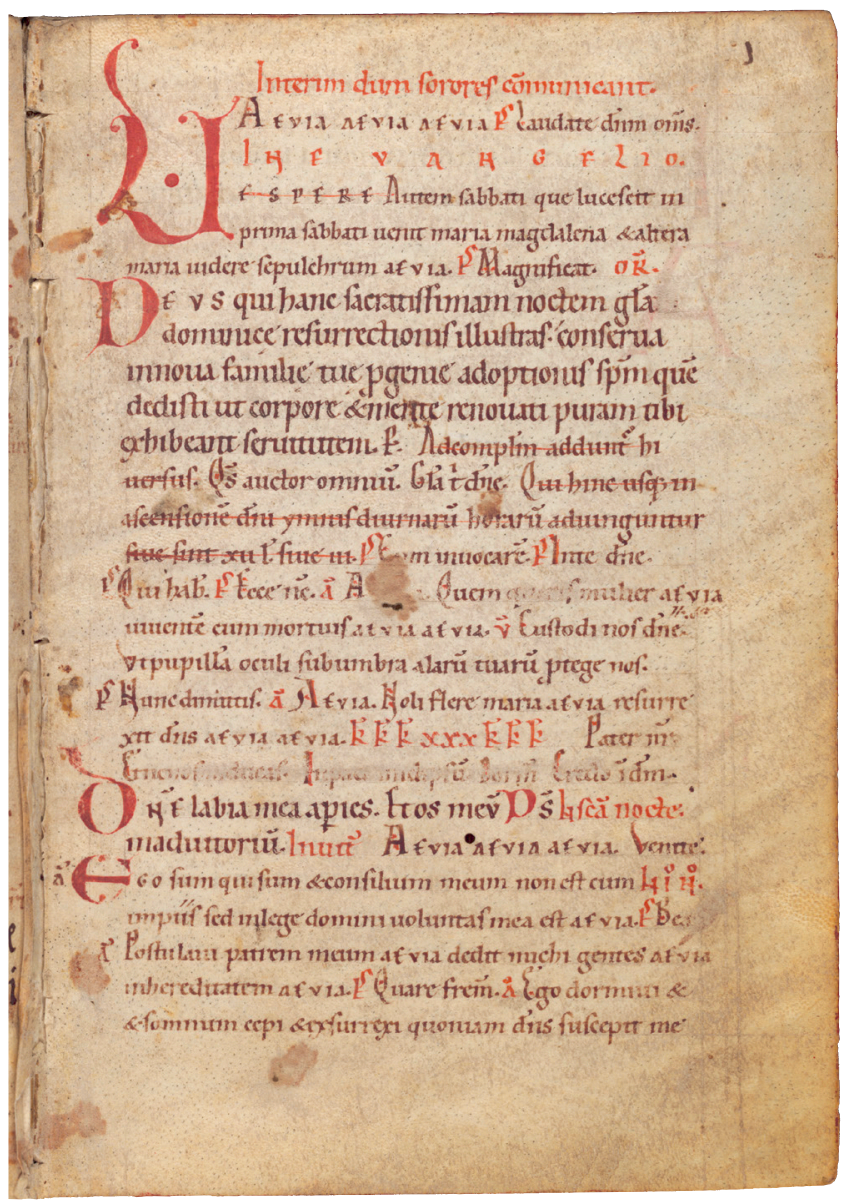

Obr. 1. Breviarium. Praha, Národní knihovna ČR, sign. NK VI.E.13, fol. 1r. Foto: NK.

Breviarium, počátek 14. století, NK VII.G.17d; Hymnarius, 14. století, NK VII.H.1; Breviarium, počátek 14. století, NK XII.A.22; Breviarium, počátek 14. století, NK XII.D.8a; Breviarium, počátek 14. století, NK XII.D.8b; Breviarium, počátek 14. století, NK XII.D.9; Dialogus beatae Mariae Virginis et Anselmi alii textus, počátek 14. století, NK XII.D.10; Preces, počátek 14. století, NK XII.D.11; Preces, počátek 14. století, NK XII.D.12; Pseucho-Prochorus: Acta sancti Johannis et alii textus, počátek 14. století, NK XII.D.13; Breviarium, poslední třetina 14. století, NK XII.E.1; Processionale; první třetina 14. století, NK XII.E.15a; Corpus officiorum, 14. století, NK XII.E.15b; Hymnarius, počátek 14. století, NK XII.E.15c; Breviarium, konec 13. století, $N K$ XII.F.5; Breviarium, konec 13. století, NK XII.F.9; Psalterium, druhá polovina 13. století, NK XII.G.8; Psalterium, konec 13. století, NK XII.G.11a; Breviarium, polovina 13. století, NK XII.G.20a; Psalterium, druhá polovina 13. století, NK XII.G.20b; Fragmentum praebendarum, polovina 14. století, NK XIII.A.225; Breviarium, počátek 15 . století,

\footnotetext{
${ }^{18}$ WATT 2007

${ }^{19}$ BELL1995.

${ }^{20}$ Zejména HAMBURGER 1997; HAMBURGER 1998.

${ }^{21}$ MENGIS 2013.

22 BABCOCK 1993; RÜCK - BOGHARDT 1994; EMBACH - RAPP 2008.

${ }^{23}$ BASTL 2004.

${ }^{24}$ Rukopis je nejspíše břevnovského původu, ale nejpozději ve 13. století byl upraven pro potřeby svatojiřského konventu.

${ }^{25}$ Rukopis má nezpochybnitelnou vazbu na sbor svatojiřských kanovníků.
} 


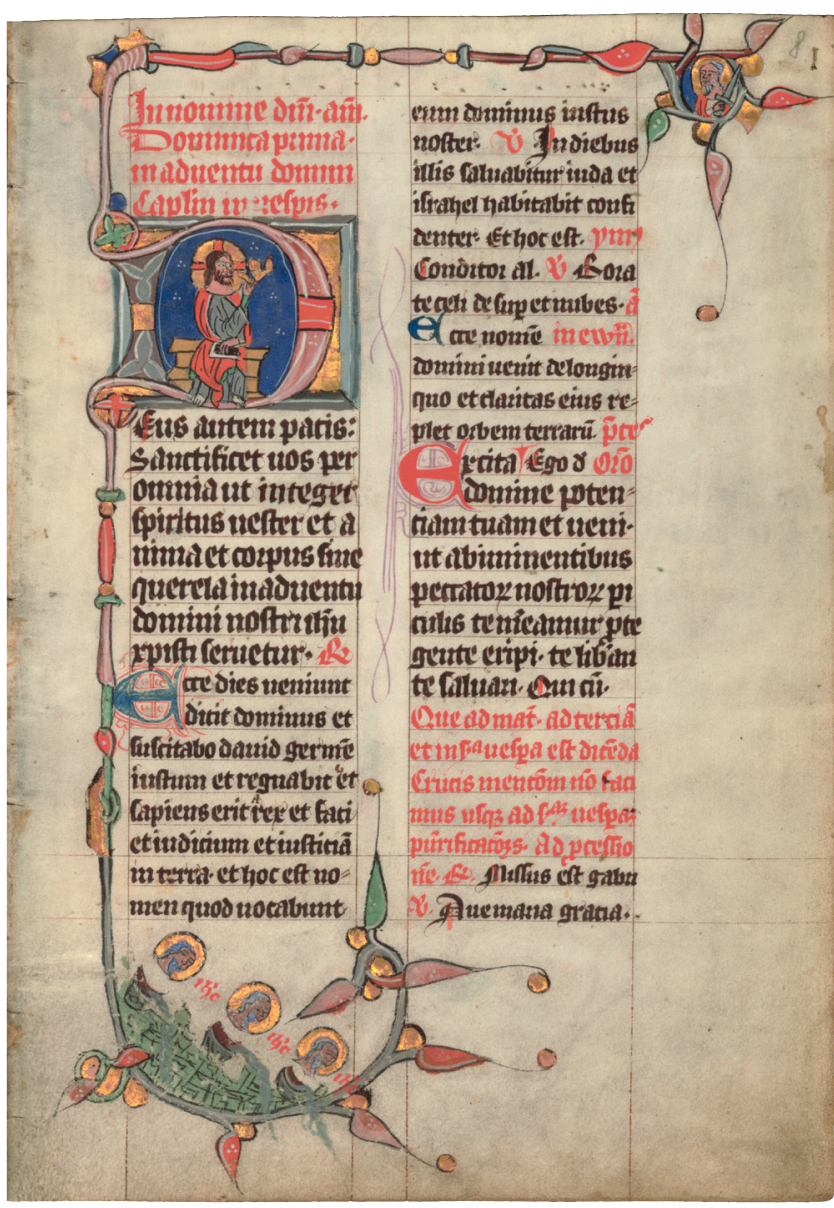

Obr. 2. Breviarium. Praha, Národní knihovna ČR, sign. NK XIII.E.14e, fol. 8r. Foto: NK.

NK XIII.B.9; Breviarium, konec 14. století, NK XIII.C.1a; Breviarium, 2. třetina 14. století, NK XIII.C.1b; Antiphonarium, 13./14. století, NK XIII.C.4; Breviarium, druhá polovina 14. století, NK XIII.C.5; Antiphonarium, 13./14. století, NK XIII.C.7; Psalterium, druhá polovina 12. století, NK XIII.E.14b ${ }^{26}$; Bernardus Claraevallensis: Sermo CIV, Bonaventura: Lignum vitae et alii textus, 1303, NK XIII.E.14c; Liber ordinarius, 1347-1365, NK XIII.E.14d; Breviarium, polovina 14. století, NK XIII.E.14e; Breviarium, počátek 14. století, NK XIII.E.14f; Processionale, počátek 14. století, NK XIII.H.3c; quod dicitur Passionale abbatissae Cunegundis, 1313-1321, NK XIV.A.17; Antiphonarium, první polovina 14. století, NK XIV.B.13; Antiphonarium, 13./14. století, $N K$ XIV.C.20; Breviarium, konec 13. století, KNM XIV.D.1327; Expositiones super Ave Maria, 1306, NK XIV.D.13; Psalterium, polovina 14. století, KNMXVI.A.1828; Opera varia, 1312 ,
NK XIV.E.10; Breviarium, 14. století, NK XIV.F.12; Corpus officiorum, počátek 14. století, NK XIV.G.46; Klementinská legenda o sv. Jiř́, konec 14. století, NK XVII.J.17/11; Breviarium, konec 14. století, NK XXIII.D.138; Breviarium, 1359, NK XXIII.D.142; Breviarium, polovina 14. století, NK XXIII.D.155; Breviarium, 12./13. století až první polovina 14. století, NK XXIII.D.156) ${ }^{29}$. Ve svatojiřské knihovně jednoznačně dominovala liturgika, určená jednak pro liturgickou praxi a dále také sloužící pro vzdělávání novicek.

Ve sledovaném období zaznamenáváme výrazný propad rukopisné produkce. Postupně se objevují rukopisy, které mají výrazně nižší kvalitu (uměleckou a obsahovou) a které odkazují k některé ze sester jako možné písařce a tvůrkyni jednoduchých iniciálek. ${ }^{30} \mathrm{Z}$ linie prostých rukopisů vybočují zejména iluminované hodinky XVII G 3 z osmdesátých let 15. století, u nichž je prípadný svatojiřský původ prozatím nepotvrzen. Jistě určené processionale NK XIV.D.21 navazuje na liturgické zvyklosti kláštera. Svatojiřské abatyše také ad hoc vystupovaly jako dedikantky knih, at' už v rukopisné formě (abatyše Kunhuta na počátku 14. století v sérii rukopisů, např́klad tzv. Pasionál abatyše Kunhuty NK XIV.A.17, a abatyše Kunhuta $\mathrm{z}$ Kolovrat v poslední čtvrtině 14. století, vyobrazená v breviári NK XIII E 14a, 1365-1385 a v breviáři NK XIII E 1 z roku 1386), nebo v tištěné (viz Hortulus anime. Zahradka dusse, vytištěná 1520 u Hieronyma Höltzela v Norimberku, ${ }^{31} K N M 25 F 8$ a NK $54 F 256$ s dedikací abatyši Johance z Velhartic nebo Augustinus Aurelius. Pobožné dwoge Kázanij Swatého Augustyna času Adwentnijho $w$ Cžeský Jazyk přeložené a knaučenij y k potěssenij wěrných Dussý Křestianských wydané...s.l.: 1567 /NK 54 E 59, KNM $36 \mathrm{~A} 2$ / věnované abatyši Dorotě z Krumlova k roku 1567). ${ }^{32}$

Identifikace tiskủ z této klášterní knihovny by si zasloužila větši pozornost, než jakou jsem jí mohla dosud věnovat. Nejistě byl identifikován jen jeden svazek. ${ }^{33}$ Při bližším prozkoumání předávacích seznamů pocházejících z období rušení kláštera je zcela zjevné, že tento výčet není kompletní. ${ }^{34}$ Prozatím se nepodařilo identifikovat graduály a misály (stejně tak jako dalš́ liturgika), která byla souč́stí knihovny a u nichž lze očekávat mladší původ, snad právě z tohoto období. Obdobně se nepodařilo nalézt řadu dalších, v seznamu uvedených tisků z tohoto období (Anima fidelis seu opus super epistolas totius quadragesimae. Lugduni per Joann. De Vingle 1494; Breviarium Horarum Canonicarum Secundum Rubricam Ecclesiae Archiepisc. Pragens. Impensis Georgii Furchs de Sultzpach. Nürnbergae 1502; Missale Pragense. Bamberg: [Johann Sensenschmidt et Heinrich Petzensteiner], 1489 $9^{35}$; Missale emendatum juxta rubricam Pragensis Ecclesiae [Missale Pragense] Leipzig: Conrad

\footnotetext{
${ }^{26}$ Rukopis pochází z blíže neznámého ženského kláštera, ale nejpozději ve druhé polovině 13. století se nacházel v majetku svatojiřského konventu. Zároveň byl také $\mathrm{v}$ této době upraven pro potřeby svatojiřského konventu.

${ }^{27}$ Rukopis je původem nejspíše z kláštera benediktinek v Teplé. Již na konci 13. století byl přesunut do svatojiřského konventu, kde byl doplněn o svatojiřské reálie.

${ }^{28}$ Rukopis byl zhotoven ve svatojiřském skriptoriu, ale již záhy po svém dokončení byl přesunut a doplněn o reálie karlštejnských kanovníků.

${ }^{29}$ Blíže MODRÁKOVÁ 2019, tam uvedeny podrobnosti ke vzniku řady rukopisů.

${ }^{30}$ Zejména psalterium I H 8 a, psalterium I H 8 b datovaná na přelom 15. a 16. století.

${ }^{31}$ Blíže popis BOLDAN v STUDNIČKOVÁ - BOLDAN - MODRÁKOVÁ 2019, s. 133-138.

${ }^{32} \mathrm{~K} 00861$.

${ }_{33}^{33}$ Das Leben Jesu Christi gezogen aus der 4. Ewangelisten. Strassburg durch Johann Knoblauch, 1508 (VD16 B 4651).

${ }^{34}$ Archiv Národní knihovny $\breve{C} R, V K U$, č. kartonu 84 (benediktinky u sv. Jiří).

${ }^{35}$ ISTC im00685000.
} 
Kachelofen, 149836; Passional genannt das Leben der heiligen Transl. Strassburg durch Johann Grüninger 1510; Passional bohemice Pragae 1495). Během sledovaného období si konvent vystačil se staršími dochovanými kodexy. Kvůli tomu, že bylo personální složení konventu během 15. století a zejména v 16. století průběžně oslabováno, neměl zjevně potřebu systematicky doplňovat svoji knihovnu. Ve srovnání s dalšími českými a moravskými ženskými kláštera si i nadále podržel pozice významné klášterní instituce. $\mathrm{V}$ rámci možností se také začal orientovat na tištěnou produkci.

\section{Knihovna kláštera premonstrátek v Doksanech}

Nejstarší klášter premonstrátek byl založen v letech 1143 až 1144 jako druhý nejstarší klášter českých zemí. ${ }^{37}$ Podobně jako klášter benediktinek to byla přemyslovská fundace zajištěná četnými movitými i nemovitými majetky. Během husitských válek byl klášter opuštěn. V následujícím období se konvent zaměřil na opravy klášterních budov a stabilizaci vnitřních poměrů. Klášterní budovy přebudované dle pravidel barokního slohu dokládají silný potenciál konventu během 17. století. Jako další ženské kláštery byl zrušen během josefinských reforem a jeho knihovna byla přesunuta do dnešní Národní knihovny.

Ze staršího období klášterní knihovny se dochovalo jen malé množství rukopisů (liturgika, nekrologium, úřední knihy). Malý rozsah dochovaných kodexů vyvolává přirozeně četné dotazy. Takto významný klášter, jenž byl panovnickou fundací a do něhož byly dávány přemyslovské dcery (Anežka, pozdější svatojiřská abatyše, svatá Anežka na počátku 13. století) s největší pravděpodobností disponoval dostatečným rukopisným korpusem. ${ }^{38} \mathrm{Z}$ pohusitského období se dochoval jediný právní rukopis (Donat, český překlad magdeburské, po prípadě saské městské právni knihy zvané Weichbildvulgata, 1547, NK XVII.C.24).

$\mathrm{Z}$ tištěné produkce je zachována jedna jediná inkunábule Crescenzi, Pietro de. Ruralia commoda. Strasbourg: Jordani de Quedlinburg, 9.III.1486. ${ }^{39}$ Předávací seznamy z Archivu Národní knihovny k tomu uvádí ještě další, prozatím neidentifikovaný titul Postilla super Evangelia Dominicalia, et de Sanctis secundum sensum literalem collecta. Argentinae (1489). ${ }^{40}$ Podobně jako v príípadě Chotěšova se premonstrátky začaly zabývat knižními nákupy až $\mathrm{v}$ pokročilém 16. století (např́klad Hieronymus Brunschwig: Liber de arte Distillandi de Compositis. Straßburg: Grüninger, Johann, 1512, NK 18 A 134). ${ }^{41}$ Pro mladší období (zhruba od druhé poloviny 16 . století prakticky až do zrušení kláštera v rámci josefinských reforem) je jenom ve fondech Národní knihovny dochováno více než sto exemplářu. Tento stav byl s největší pravděpodobností dán nestabilními ekonomickými podmínkami, nutností primárně opravit poničené klášterní budovy a znovuobnovit vnitřní fungování a základní činnosti konventu.

\section{Knihovna kláštera premonstrátek v Chotěšově}

Bývalý klášter premonstrátek v Chotěšově byl založen na počátku 13. století blahoslaveným Hroznatou na žádost jeho sestry Vojslavy. Jedno z největších období rozkvětu prožil zejména ve druhé polovině 14. století. Během husitských válek byly do značné míry poškozeny klášterní budovy. Dnešní podoba je více méně barokní, vzniklá krátce před jeho zrušením v roce $1782 .{ }^{42}$

O stavu klášterní knihovny nejlépe svědčí soupis z května $1782 .{ }^{43}$ Největší množství kodexů je v současnosti dochováno v historických sbírkách Národní knihovny, a to jednak $\mathrm{v}$ části $\mathrm{z}$ tzv. zrušených klášterů a dále $\mathrm{v}$ nedávno získané sbírce rukopisů a inkunábulí kláštera v Teplé. ${ }^{44}$

Knihovna byla budována již od nejstarších dob fungování chotěšovského konventu. Jedním z nejznámějších stř̌edověkých rukopisů z této knihovny je tzv. Misál chotěšovského kláštera z roku 1340 (NK XIV.C.3) a dnes již nedostupný Sulkưv misál.

$\mathrm{Z}$ předhusitského období se dochovaly jen některé tituly (Breviarium ordinis Praemonstratensis (?) cum benedictionibus et aliis additamentis, 13. století, NK XIV.E.15; Psalterium, 14. století, NK XIII.D.18; Breviarium, 1353, NK VII.F.23; Breviarium, 14. století, Teplá MS. b 13; Bertrandus de Turre: Sermones super epistolas dominicales; Pantheon miraculorum, 1326-1354, NK XII.D.6; Agenda monasterii Chotiessoviensis, druhá polovina 14. století, Teplá MS. D 4; Missale, polovina 14. století, NK XIV.C.3). Podobně jako $\mathrm{v}$ předcházejícím prrípadě svatojiřského kláštera převažovala liturgika.

Ze sledovaného období to byla opět zejména liturgika (Responsorium, 1482, Teplá MS. b 18; Antiphonarium perpetuis notis musicis instructum et usui ord. Praemonstratensis adaptatum, 1524, NK VII.F.13) a úřední písemnosti knihy (Registrum censuum et proventuum monasterii Chotěšoviensis, 1510, NK XV.A.5; Urbář kláštera Chotěšovského, počátek 16. století, $N K X V . A .4)$. Nejspíše k třístému výročí úmrtí blahoslaveného Hroznaty byla sepsána druhá redakce Vita fratris Hroznatae, Teplensis et Chotiessowiensis monasterii fundatoris z roku 1517 (Teplá MS.b.1), svázaná v typické pozdně gotické vazbě s kovovými puklicemi. Výjimečným materiálem jsou zejména Latinské hodinky chotěšovské panny Johanky z 15. století (NK XVI.G.31). Cenným zdrojem pro poznání dějin konventu ve sledovaném obdo-

\footnotetext{
${ }^{36}$ ISTC im00686000.

${ }^{37}$ MIKA 1726.

${ }^{38}$ Hledat důvody toho, proč se dochoval tak fragmentární počet titulů, je vždy velice obtížné a překračuje možnosti tohoto př́ispěvku. Hypoteticky lze uvažovat o vlivu velkých požárů, zejména kolem roku 1200, a také válečných událostí (poničení budov během husitských válek).

${ }^{39}$ Křivoklát 22 d 25, ISTC ic00968000.

${ }^{40}$ Nejspíše ISTC ig00687000.

${ }^{41}$ VD 168698

${ }^{42}$ Blíže zejména HLINOMAZ 2009.

${ }^{43}$ Národní archiv v Praze, fond Česká státní účtárna, inv. č. 2056, karton č. 323.

${ }^{44} \mathrm{~K}$ rukopisům zejména HOFFMANN 1999.
} 


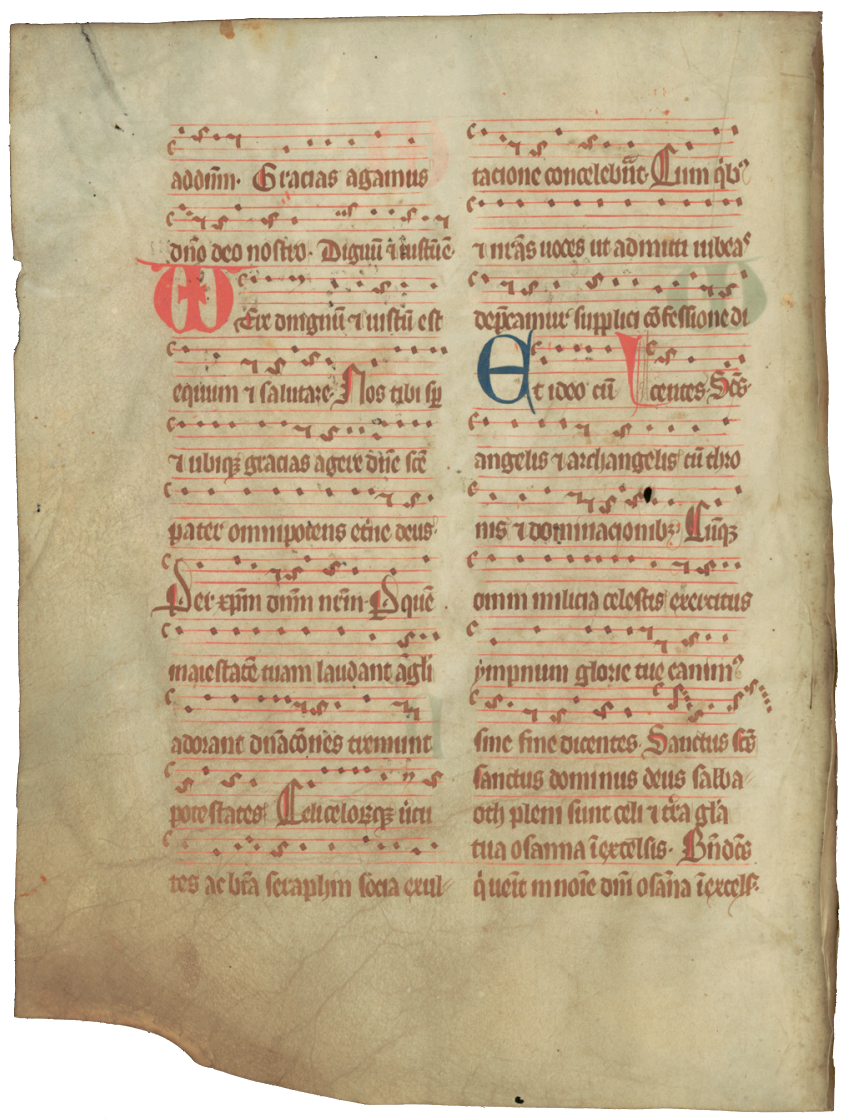

Obr. 3. Misál chotěšovského kláštera. Praha, Národní knihovna ČR, sign. NK XIV.C.3, fol. 185v. Foto: NK.

bí je zejména martyrologium s nekrologiem z roku 1489 (NK XIII.G.20). ${ }^{45}$

$\mathrm{V}$ prrípadě některých kodexů je nutné rozlišit, zda byly součástí klášterní knihovny nebo $\mathrm{v}$ soukromém vlastnictví některého z proboštů. Takovým př́kladem je psalterium NK Teplá B 40 vytištěné v Lipsku u Mauritia Brandise (30. 3. 1485) se znakovým supralibros a iniciálami Adama Rudrische, chotěšovského probošta (1633-1639). ${ }^{46}$ Dalším podobným případem je inkunábule Albumasara Introductorium in astronomiam, vytištěná v Augsburgu u Erharda Ratdolta v roce $1489^{47}$ pocházející ze soukromého vlastnictví Georga Ssparamstla (Teplá B 43). Chotěšovský kaplan Johann Grisbach vlastnil v roce 1545 Miscellanearum libri duo Friedricha Nausea vytištěné v Kolíně nad Rýnem u Petera Quentella v roce 1531 (Teplá B 200). ${ }^{48}$

Zejména během 16. století byly zakoupeny nebo darovány inkunábule, postinkunábule a paleotypy, které značnou měrou rozšíríily klášterní knihovnu. Některé byly zakoupeny prímo ve sledovaném období (Liber Octo questionum

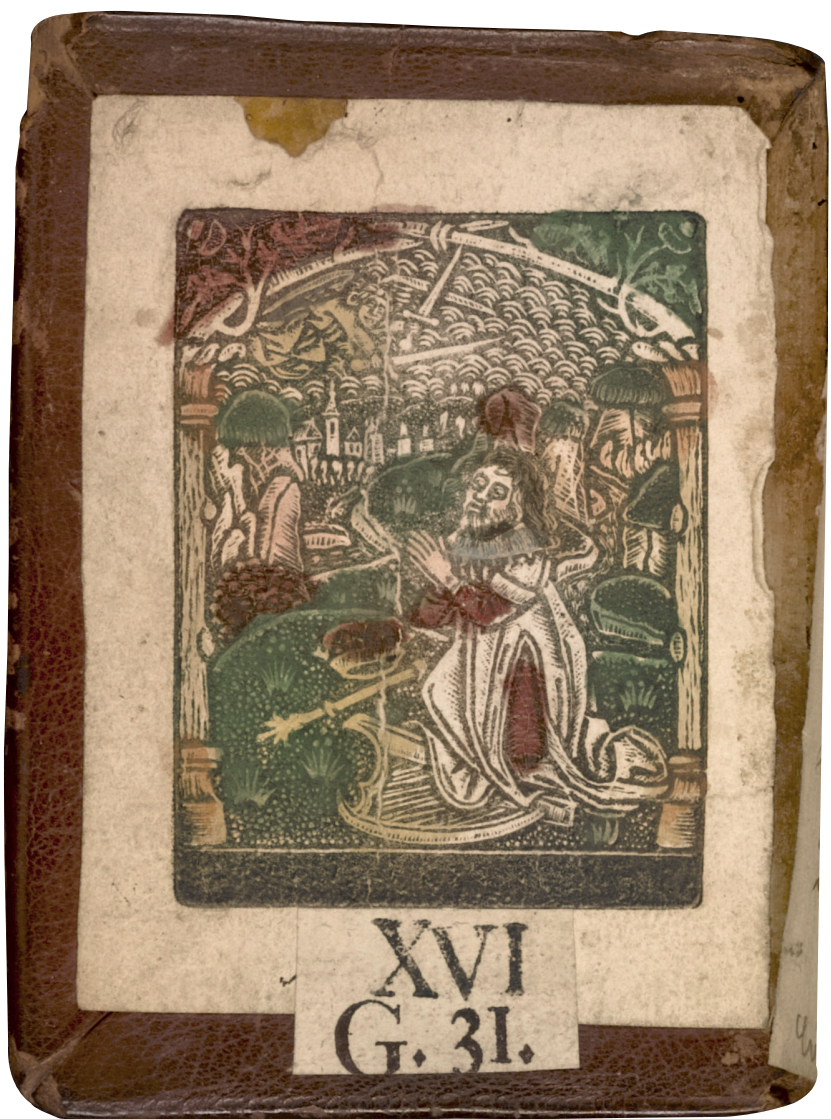

Obr. 4. Latinské hodinky chotěšovské panny Johanky. Praha, Národní knihovna ČR, sign. NK XVI.G.31, dřevořez na PP. Foto: NK.

ad Maximilianum Caesarem od Jana Trithemia, vytištěné v Oppenheimu u Johanna Hasselberga v roce 1515, Teplá B 110, ${ }^{49}$ obsahující rukopisné provenienční poznámky chotěšovského kláštera na předním prrídeští; dále Discipulus de eruditione chrisfidelium compendiosus od Johanna Herolta, vytištěné ve Štrasburku u Martina Flacha 1509, Teplá $C 115,{ }^{50}$ obsahující soudobou vlastnickou poznámku; nejistě také Catalogus sanctorum et gestorum eorum ex diversis voluminibus collectus od Pietra Nataliho, vytištěné v Lyoně u Jacqua Saccona 9. 12. 1514, Teplá D 81;51 Concordantiae maiores sacrae scripturae Conrada z Halberstadtu, vytištěné ve Štrasburku u Georga Ulricha v roce 1529, Teplá E 98). ${ }^{52}$ Jiné se staly součástí knihovny později (nejspíše Sermones de tempore et de sanctis, sive Hortulus reginae Meffretha, vytištěné v Basileji u Nicolause Kestlera kolem roku 1483, Teplá D 253; Autores historiae ecclesiasticae od Eusebia z Caesareje vytištěné v Basileji u Johanna Frobena $\mathrm{v}$ roce 1523, NK 21 B 70 a Sb 3954; Interpretamenta litterarum Marca Valeria Proba vytištěná v Oppenheimu nejspíše

\footnotetext{
${ }^{45}$ Blíže zejména GRASSL1931.

${ }^{46}$ Konkrétně ISTC ip01044850, HLINOMAZ 2000 č. 442.

${ }^{47}$ ISTC ia00359000, GW 840; HLINOMAZ 2000, č. 18.

${ }^{48}$ VD 16 N 249, VD 16 259, VD 16 266; HLINOMAZ, č. 537. To dosvědčuje jeho vlastnická poznámka na rubu 50. listu.

49 VD 16 T 1986; HLINOMAZ 2000, č. 693.

${ }^{50}$ VD 16 H 2567; HLINOMAZ 2001, č. 244.

${ }^{51}$ HLINOMAZ 2001, č. 535

52 VD 16 C 4905, VD 16 J 758; HLINOMAZ 2001, č. 209.

${ }^{53}$ ISTC im00440000, GW M22646; HLINOMAZ 2000, č. 349.

${ }^{54} \mathrm{VD} 16 \mathrm{E} 4273$.
} 
u Köbela v roce 1510, NK 6 H 2655; Io. Frobenius Studiorum Liberalium Mystis Erasma Rotterdamského vytištěné v Basileji u Johanna Frobena v roce 1520, NK 8 B 7156; Sermones de adventu Oliviera Maillanda vytištěné ve Štrasburku u Johanna Knoblocha v roce $1506, N K 34$ D 254) ${ }^{57}$. K roku 1629 je zaznamenán starší titul Zeiglöcklein des Lebens und Leidens Christi od Bertholda, vytištěn v Norimberku u Friedricha Creussnera 11. 5. 1489 (Teplá A 19) s větším množstvím rytin. ${ }^{58}$ Ten však nejspíše dorazil do klášterní knihovny až později. Obdobně je k roku 1651 poznamenáno Quattuor sententiarum volumina Petra Lombardského s komentáři vytištěné v Benátkách u Lazara Soarda 23. 3. 1507 (NK Teplá B 134), u kterého musíme opět předpokládat pozdější příchod do klášterní knihovny. U některých zůstává lokace do chotěšovského kláštera poněkud nejistá, i když značně pravděpodobná (Breviarium praemonstratense vytištěná v Alost u Theodorica Martiniho v roce 1488, Teplá B 91). ${ }^{59}$ Předávací seznamy v Archivu Národní knihovny navíc uvádí další tituly, které se prozatím nepodařilo ztotožnit s konkrétními originály. ${ }^{60}$
Četná specifika ve skladbě titulů byla ostatně dána blízkou vazbou na mužský klášter premonstrátů v Teplé, odkud pocházeli duchovní správci sester a kam byly po zrušení kláštera četné chotěšovské originály přesunuty. Chotěšovské premonstrátky se ve sledovaném období zaměřily na nákup tištěné produkce. $\mathrm{V}$ př́padě jejich knihovny evidujeme dle předávacích seznamů největší počet inkunábulí. Při nákupech se orientovaly především na německý prostor. Zjevně se také snažily udržovat korpus základní liturgické literatury. Jedním z jejich hlavních zájmů bylo stabilizovat ekonomickou pozici kláštera, k čemuž by mohlo odkazovat větší množství úředních knih.

\section{Knihovna kláštera dominikánek u svaté Anny na Starém Městě pražském}

Původní konvent dominikánek vznikl již na sklonku 13. století na Újezdě pod Petrrínem na Malé Straně Pražské. O něco málo později byl přesunut do prostor bývalé templářské komendy na Starém Městě. Ten fungoval v úzkém sepětí

${ }^{55}$ VD 16 P 4934, VD 16 P 4158.

${ }^{56} \mathrm{VD} 16 \mathrm{E} 1936$

57 VD 16 M 241.

${ }^{58}$ Blíže HLINOMAZ 2000, č. 101; nejspíše ISTC ib00513000 z roku 1493.

${ }^{59}$ ISTC ib01143970; GW 5230; HLINOMAZ 2000, č. 152. Rukopis je opatřen tepelskou vazbou (EBDB w003400), ale přípisek na předním přídeští "Famula Christi attende " odkazuje k blíže neurčené řádové sestře.

${ }^{60}$ Předávací seznamy jsou vesměs strohé bez uvedení jasných titulů. Nepřesnosti a nejasné znění vedly k tomu, že ne všechny tituly se podařilo blíže identifikovat. Alexandri Glossa Primae et Secundae partis cum notabilibus et argumentis quibusdam Lipsiae apud Conr. Kacheloven, 1491 [pravděpodobně Alexander de Villa Dei: Doctrinale Pars I. Leipzig: Conrad Kachelofen, 1491; ISTC ia00441400], Eiusdem item tertia et quarta pars doctrinalis ibidem ad eodem [pravděpodobně Alexander de Villa Dei: Doctrinale Partes III et IV. Leipzig: Conrad Kachelofen, cca 1491; ISTC ia00452940]; Antonii Summa Confessionis Venetiis 1495. Eodem Summa; Bernecker, Johann Adam: Album Augustissimae Domus HabspurgicoAustriacae, Pragae apud Wolfgang Wikhart 1513; Biga Salutis sive Sermones de Sanctis Haganaoae 1502 [Lasko, Osvald: Sermones de sanctis, Hagenau: Heinrich Gran; Augsburg: Johann Rynman, 1502; VD 16 1422]; Biga Salutis sive Sermones Dominicales, Haganaoae 1498 (ISTC io00117400); Coelifodina et Epistolae quaedam. Erfordiae per Wolfg. Scheuker 1502; Comestor, Petrus: Scholastica historia S. Scripturae seriem exponens Argentinae 1485 (ISTC ip00463000); Concordantia discordantium. S.1. 1489; Dorme secure seu Sermones de tempore, Argentinae 1493 [Johannes de Verdena: Sermones „Dormi secure“ de tempore et de sanctis, Strassburg: Georg Husner, 1493-94, ISTC ij00465000]; Gritschii, Joan.: Quadragesimale 1495 [Venice: Lazarus de Suardis, de Saviliano, 21 Mar. 1495, ISTC ig00506000; Lyons: Johannes Trechsel, 27 Apr. 1495, ISTC ig00507000; Strassburg: Printer of the 'Casus Breves Decretalium' (Georg Husner?), 31 Dec. 1495, ISTC ig00508000, Basel: Michael Furter, 1495, ISTC im00421000], in eodem Bartolus de Saxoferrato: Modus legendi Abbreviaturas in utroque iure, Argentinae 1504; Guillermus: Postilla super epistolas et evangelia totius anni. Augustae 1495 [Guillermus: Postilla super epistolas et evangelia. Strassburg: Johann Prüss, cca 1495; ISTC ig00663000]; Historia Lombardica seu Legenda Sanctorum, Argentinae 1490 (ISTC ij00124000); Historia Lombardica seu Legenda Sanctorum, Argentinae 1486 (nejspíše ISTC ij00117000); Jacobi Januensis Legenda Sanctorum quae Lombardica nominatim historia, Argentinae 1496 (ISTC ij00133000 nebo ISTC ij00134000); Janua, Joannes de: Summa quae vocatur Catholicon, Norimbergae 1483 (ISTC ISTC ib00025000); nejistě Kniha Chwal Bozskych, s.1. 1499; Lavacrum conscientiae omnium sacerdotum, Augsburg 1492 (ISTC il00098000); Lochmayr, Michal: Sermones de Sanctis, Haganoae 1494, tentýž autor Sermones de sanctis, Haganoae 1497 (ISTC il00271000); Lombardi Petri: Textus Sententiarum cum conclusionibus M. Henrici Gorchen, Basileae 1498 [Petrus Lombardus: Sententiarum libri IV. Comm: Henricus de Gorichem. Add: Articuli in Aglia et Parisiis condemnati. Basel: Nicolaus Kessler, 20.2.1498; ISTC ip00496000]; Lyra, Nicol de: Postillae super librum Psalmorum Pariis 1483 [Nicolaus de Lyra: Postilla super Psalterium. Paris: Ulrich Gering, 5.11.1483; ISTC in00123000]; Michaelis Medolanensis Sermonarium de poenitentia, Venetiis 1496 (ISTC ic00197000); Passional neb Ziwot a Umuczenij wssech swatych Muczedtnikuw w Praze 1495; Passional das ist Leben der heiligen... Augsburg 1485 (nejspíše Jacobus de Voragine: Legenda aurea sanctorum, sive Lombardica historia [German] Leben der Heiligen: Winterteil (I) und Sommerteil (II). Augsburg: [Johann Schönsperger], 1485, ISTC ij00162000); Pauli D. Epistolae quatuordecim juxta D. Hieronymo translationem Liptzig 1514; Aristotelis Stagiritae Philosophorum maxime oeconomicorum libri duo translati egraece in latinum a Leonardo Arethino ibid. 1511 (VD16 A 3416); item Psalterium Davidis per D. Auretium August. In tres quinquaegenas divisum ibid. 1514; Pelbarti de Temesvar De observantiae, Hagenaw 1511 (VD16 P 1188); Pelbarti Pars aestivalis Sermonum de Sanctis. Hagenaw 1499 (ISTC ip00250000); Pelbarti Sermones de tempore 1508; Pelbarti Sermones Pomerii de Sanctis, 1501; Philethi, Franc.: Epistolae, Basileae 1495; Pomponii, Laeti: De Romanorum Magistratibus, Sacerdotibus, Jurisperitis et Legibus ad M. Pantagotum Libellus. Bononiae 1495 (tamtéž také Aenae Sylvio De situ moribus et conditione Theutonicae descriptio, Leipzig 1496, ISTC ip00744000); Solinus de Mirabilibus mundi, Venetiis 1491 (ISTC is00620000); Corvini, Lauri: Cosmographiae dans manuductionem in tabulas Ptolemaii ostendens omnes regiones, terrae, habitabiles diversa hominum genera diversis moribus et conditionibus viventes, annumerans diversae animaliae 1496 (ISTC ic00941000); Sabunde, Raymundus de: Theologia naturalis, Argentinae per Mart. Flach 1496 (ISTC ir00033000); Sermones de Sanctis per annum Dormi secure nuncupati, Argentinae 1488 (ISTC ij00459000); Sermones dominicales cum expositionibus Evangeliorum, nuncupati Dormi secure; Sermones de Sanctis, Basileae 1482 (nejistě ISTC ih00102000 nebo ISTC ih00103000); Sermones de Sanctis perutiles a quodam fratri Hungariae Ordinis minorum Biga Salutis intitulati, Hagenaw 1494; Statuta Praemonstratensis, s.1. 1500; Tractatus de arte et vero modo praedicandi, Memingae 1483; Utino, Leonardo de: Sermones aurei de Sanctis, Lugduni 1495 (ISTC i100164000); Valerii Probi et Pomponii Laeti Opuscula, Argentorati apud Schurerum, 1510; Vincentii S. Sermonum de tempore pars aestivalis, Argentinae 1489 [Ferrerius, Vincentius S.:Sermones de tempore et de sanctis. Strassburg: Georg Husner, 1488-1489, ISTC if00132000]; Vocabularius praedicantium, Lipsiae per Conradum Kachelowen, 1491 (ISTC ib01066000); Vocabularius breviloquiae utriusque Iuris, Argentinae 1495; Voragine Sermones de sanctis, Augustae 1484 (ISTC ij00188000); Wann, Paulus: Sermones de tempore, Hagenoae 1497 (ISTC iw00006000); tentýž autor i titul, 1499 (ISTC iw00007000); 


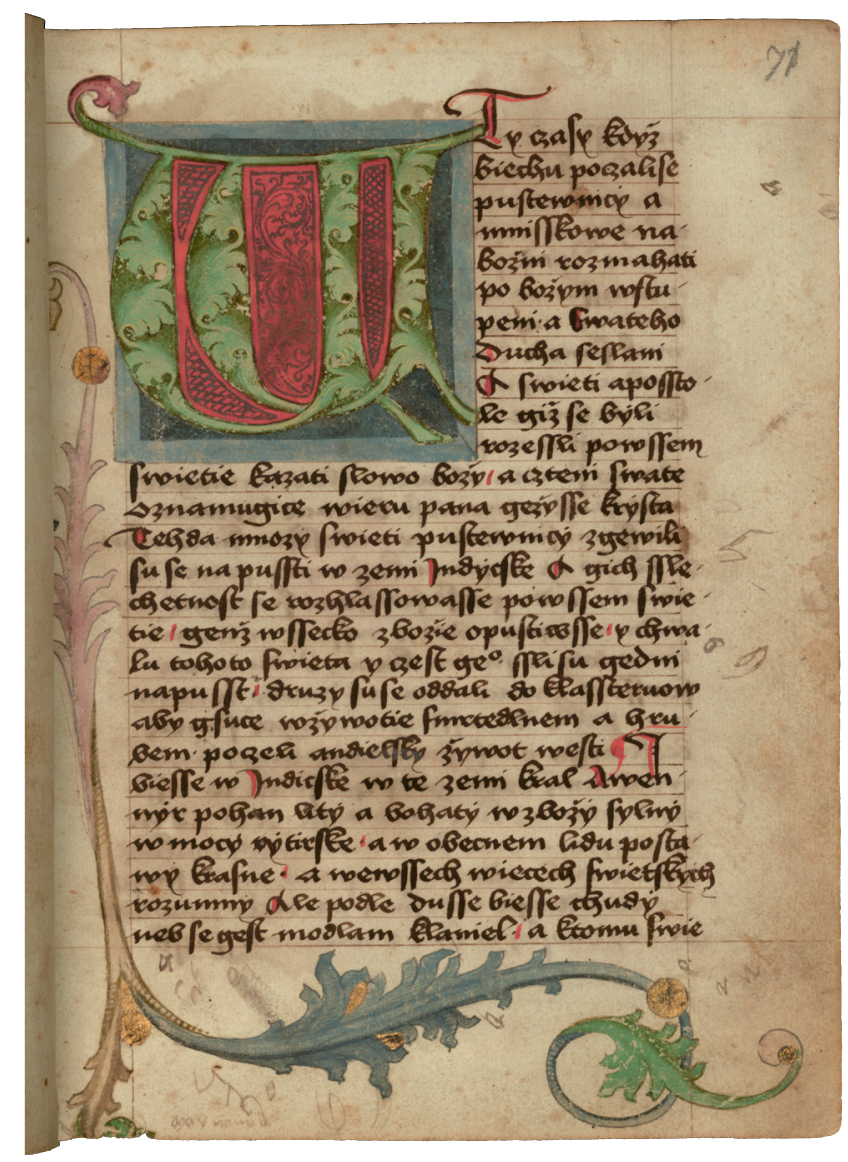

Obr. 5. Notule od kněze Jiříka. Praha, Národní knihovna ČR, sign. NK XI.D.3, fol. 71r. Foto: NK.

s blízkým klášterem dominikánů u svatého Klimenta. Vrcholným obdobím tohoto kláštera bylo zejména 14. století, během kterého byl nadán četnými majetky. V době vypuknutí husitských nepokojů sem byly internovány ráádové sestry z jiných pražských klášterů (např́klad svatojiřské benediktinky). Klášter za celou dobu své existence nebyl fatálně porušen. Podobně jako další ženské kláštery byl zrušen $\mathrm{v}$ době josefinských reforem a jeho knižní fond byl přesunut do Národní knihovny.

Při formování knihovny dominikánek lze očekávat inspirace od jejich duchovních spolubratrů. ${ }^{61}$ Lze více než předpokládat jejich vliv na tvorbu českých překladů v 14. století. Bohužel v prrípadě knihovny dominikánek u svaté Anny na Starém Městě je možné pracovat jen s menším množstvím kodexů. Ze staršího období známe Martyrologium praecedente Necrologio monasterii s. Annae Vetero-Prag ze 14. století (NK XIV.C.10).

Ve sledovaném období pracujeme s podstatně více tituly (mystické traktáty z poloviny 15 . století, NK XVI.E.14; Officia varia, Barlaam et Josafat, 1450-1525, NK XI.D.3, Notule od kněze Jiř́ka, pocházející z roku 1511, NK XVII.E.20; Řehole upravená pro potřeby jeptišek z počátku 16. století, NK XVII.F.14, Život blahoslavené Panny Kateřiny Senenské z r. 1596, NK XVII.H.8; texty sv. Jana Zlatoústého, sv. Cypri- ana v překladu Viktorina ze Všehrd, a sv. Anselma z počátku 16. století, NK XVII.H.11). Poté opět následuje zvýšená produkce rukopisů až během 17 . století. Z tištěné produkce se dochovalo Pobožné dwoge kázanij Swatého Augustyna z roku 1567 (nejistě NK 54 E 59). Pár dochovaných rukopisů dokládá $\mathrm{v}$ rámci svých omezených možností zajímavou skladbu titulů (mystické traktáty, Život Kateřiny Sienské nebo Notule).

\section{Klášter klarisek v Českém Krumlově}

Konvent klarisek v Českém Krumlově založený v polovině 14. století Rožmberky fungoval v úzkém sepětí s klášterem františkánů, prakticky ve funkci dvojkláštera. Byl nejspíše ještě provázán s komunitou zbožných laických sester (bekyň), které obývaly sousedící budovu. Nebyl zasažen husitskými válkami a ve sledovaném období zažíval jistý ekonomický a kulturní rozmach. Tato situace byla odlišná od jiných českých klášterů, bliže srovnatelná zejména s klariskami v Chebu. Oproti chebskému konventu zde ale neproběhla reforma a také přetrvala jistá jazyková pestrost (tj. kombinace němčiny a češtiny). Podobně jako další ženské kláštery podlehl i tento konvent rušení v rámci josefinských reforem. Jeho knižní fond byl následně rozptýlen, část rukopisů setrvala v Českém Krumlově ve fondu františkánském, část byla převezena do nově konstituované knihovny v Praze.

Skladba klášterní knihovny byla ovlivněna vazbou na mužský konvent. Sama Hradilová odkazuje na to, že tyto vazby vedly $\mathrm{k}$ neprůhlednému původu některých rukopisů. V okruhu mužského kláštera lze s největší pravděpodobností také hledat tvưrce většiny dochovaných rukopisů. Klarisky samy o sobě se omezovaly na role recipientek a objednavatelek. Na rozdíl od mužských členů řádu byly knihami častěji obdarovávány.

Knihovna klarisek v Českém Krumlově patřila ve sledovaném období ke spíše větším knihovním celkům. Omezovala se zejména na liturgika a kopírovala trend vlastní produkce klíčových rukopisů určených pro soukromou potřebu známý v rakouských a německých ženských konventech (zejména Necrologium monasterii ord. S. Clarae Crumloviensis, Martyrologium fr. min., 14. století, NK VI.B.9; Lectionarium, 14. století, NK XIII.A.1a; Lectionarium, 14. století, NK XIII.A.1b; Breviarium, 15. století, NK XIII.H.3.r; Breviarium, 15. století, NK VII.H.15; Breviarium, 15.-16. století, NK VII.H.12; Rituale continens agenda circa infirmas et mortuas sorores, 1529, NK XII.F.14; Antiphonarium, 16. století, NK XII.A.17; žaltář, písařem Šimon, kaplan Petrlíkovský, 1527, NK XVII.J.6; žaltář s kantikami, 1490-1520, NK XVII.F.8). V této etapě byly také opisovány četné texty s náboženskou tematikou od autorů známých z knihoven jiných ženských klášterů (Deutsche Glossen in S. Bernhards Tractat, 15. století, NK XIV.H.26; David de Augusta: Knihy o životu duchovním nábožném a Knihy o sedmeru prospívání duchovníka, 1453, NK XI.C.6; O svatém Jeronýmovi knihy troje a Povid-

\footnotetext{
${ }^{61}$ Neomezovala se jen na klášter dominikánek. Úzká spolupráce abatyše svatojiřského kláštera Kunhuty a dominikána Koldy z Koldic přinesla českým kulturním dějinám unikátní rukopis tzv. Pasionálu (NK XIV A 17).
} 


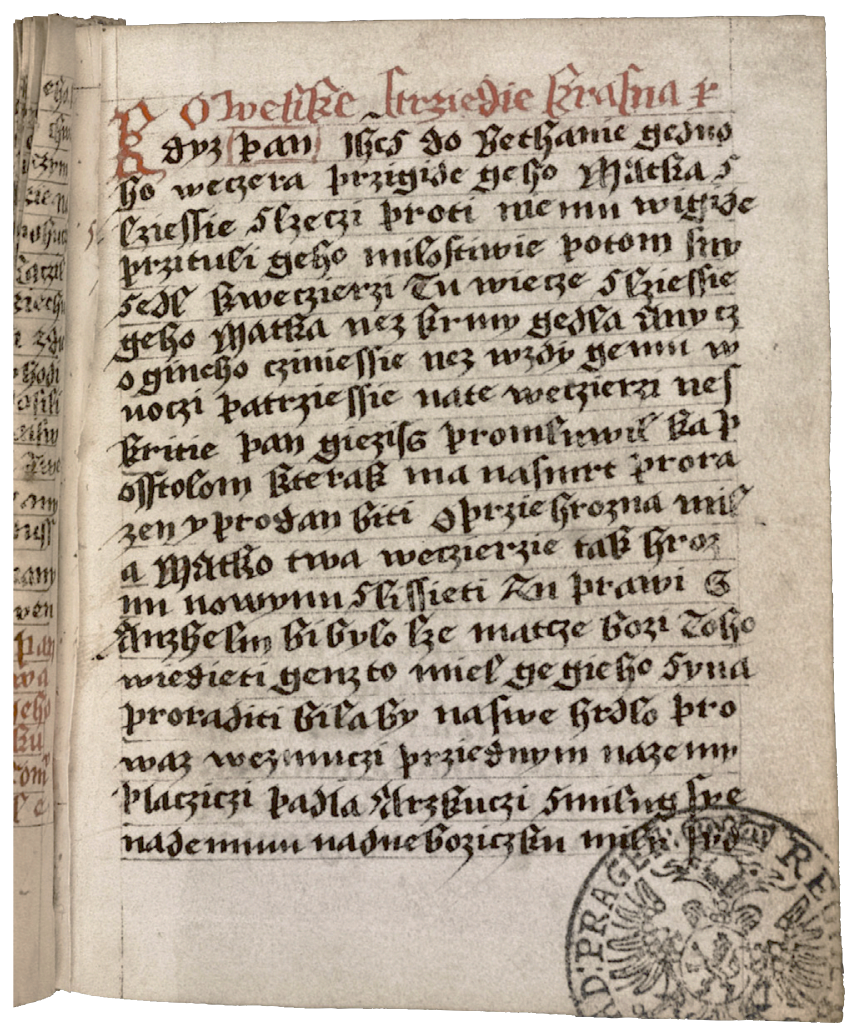

Obr. 6. Žaltář, písařem Šimon, kaplan Petrlíkovský, Národní knihovna ČR, sign. XVII.J.6, fol. 1r. Foto: NK.

ka o Tobiášovi, 2. polovina 15. století, NK XVII.E.9; Meister Heinrichs Predigt, 1514, NK XVI.A.2). U klarisek bylo $\mathrm{v}$ roce 1527 převázáno martyrologium NK VI.B.9 na žádost abatyše Alžběty známým českokrumlovským knihvazačem Bartolomějem Trnkou, kaplanem u oltáře sv. Jana Křtitele v kostele sv. Víta a českým kazatelem. ${ }^{62}$ Knihovna sloužila především potřebám samotných sester. Co se týče její rukopisné části, kromě již zmíněných středověkých rukopisů stojí za pozornost zejména české rukopisy vzniklé v 15 . a na počátku 16. století, které byly identifikovány díky soupisu a s klášterem nebyly dosud spojovány (Žaltár Alžběty, manželky rožmberského kanclére Václava z Rovného, darovaný po roce 1510; dále český žaltár̆, 1508, KNM III H 64; české modlitby, počátek 16. století, Strahov DCV 24).

Předávací seznamy uložené v Archivu Národní knihovny dokládají, že bylo předáno celkem sto šedesát tři tištěných titulů a celkem padesát devět rukopisných. Z tisků prokazatelně patří do sledovaného období pouhých šest titulů, přičemž se je nepodařilo prozatím blíže identifikovat (Breviarium Venetiis per Jac. Mentium de Leuco, 151863; Czteni a Epistoly Nedělni... Praha, 1527; Missale Romanum Venetiis per Antonium de Zanchis, 1505; Passionale i. e. Žiwot a Umuczeni wssech Swatych Muczedlnikuw w Praze 1495; Psalterius Davidis cum hymnis, Leipstik, 1514; Žal-

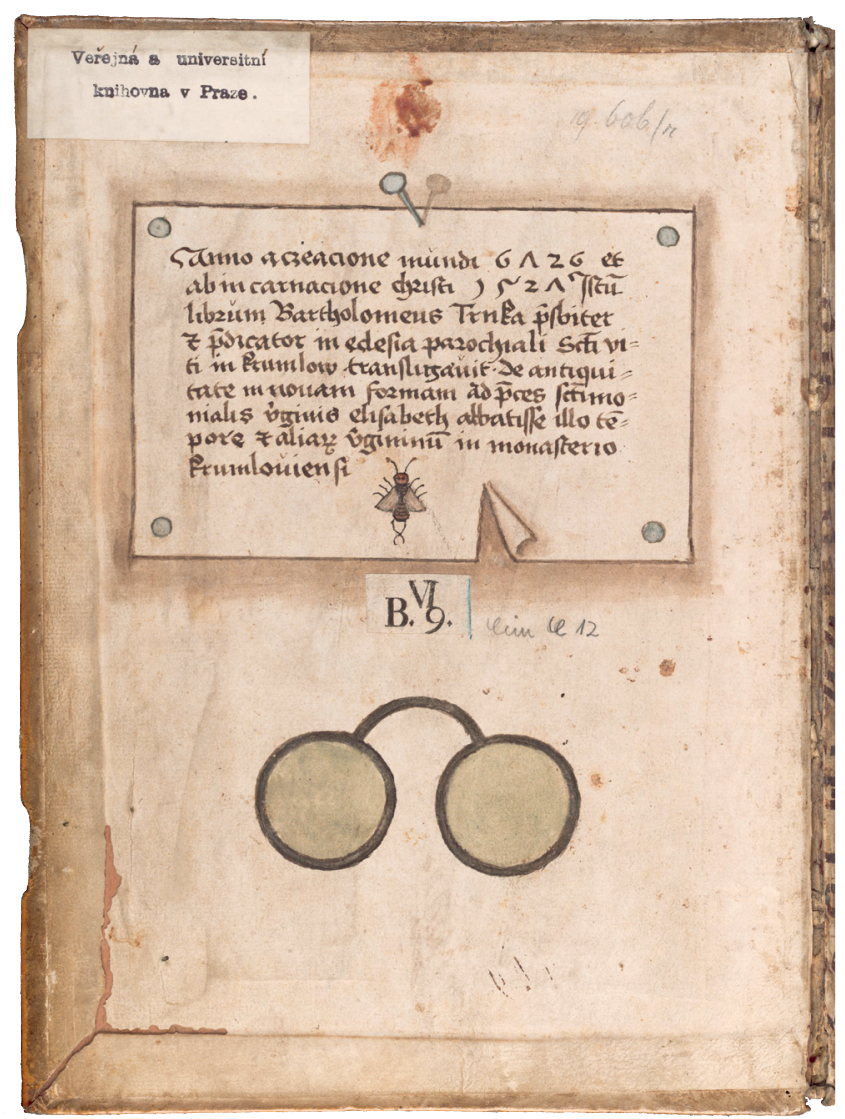

Obr. 7. Martyrologium NK VI.B.9, Národní knihovna ČR, sign. NK VI.B.9, přední prídeští. Foto: NK.

tarz y mnoho gyne pysniczky proroczke w Plzni u Mikulase Bakalarze $1508 .{ }^{64}$ Ve fondu Národní knihovny se dochovala zejména liturgika a další rukopisy, např́íklad martyrologium. Většina tiskủ byla s největši pravděpodobností rozprodána.

\section{Knihovna kláštera klarisek v Chebu}

Klášter klarisek v Chebu vznikl v šedesátých letech 13. století a podobně jako $\mathrm{v}$ př́ipadě českokrumlovském byl silně napojen na mužský klášter. Jeho zakladateli byli lokální šlechtici a po celou dobu svého fungování si udržel pozici lokálního kláštera pro dcery ze šlechtických rodin. Mezi jeho četná specifika patřila především takřka výhradní dominance německého jazyka ve všech typech dokumentů a dále silné vazby na vlivnou vrstvu chebských šlechticů a patricijů. Klášter se spíše orientoval na sousední německé země. Je to prozatím jediný klášter klarisek na území českých zemí, ve kterém je doložena během 15 . století proběhnuvší reforma a změna konventu. Stalo se tak v roce 1463 bulou papeže Pia II. ${ }^{65}$ na žádost městské rady. Ve skutečnosti byla tato reforma provedena až o dva roky později papežem Pavlem II. prostřednictvím 29. waldsasského opata Nikolause Peissera

\footnotetext{
${ }^{62}$ Blíže HRADILOVÁ 2014, s. 47.

${ }^{63}$ Nejistě VD16 XL 181.

${ }^{64}$ Knihopis K17524 (Kniehy žalmowee gsu složenee od swateho Dawida z prorokuow nai slowutniegssyeho Kterež rzestky slowu psalterium Latinie organum Zidowsky nablath Cžesky pak žaltarz).

${ }_{65}$ „Pius Episcopus-dilectis filiis in Waldsassen, et S. Egidii in Nürnberg Bambergensis, et Ratisbonensis dioecesium Abbatibus, ac Decano Ecclesiae Wratislaviensis Salutem Apostolicam. A Supremo Patre familias meritis licet in sufficientibus in Domo Domini dispensatores effecti etc. "
} 
z Chebu a řezenského kanovníka Goldina. Do Chebu přišlo pět sester z konventu v Norimberku, který prošel reformou již dříve. Původní chebský konvent se s novými změnami nesžíval poměrně nejlépe. Teprve během pěti let se podařilo situaci stabilizovat a norimberské sestry se vrátily nazpět. Na konci 15. století bylo v konventu zhruba čtyřicet sester a svým rozsahem patřil mezi větší kláštery. Dění na počátku 16. století dosvědčilo, že tento klášter byl plně samostatný, disponující značným majetkovým kapitálem se suverénními abatyšemi v čele. Stejně jako ostatní sledované kláštery byl zrušen během josefinských reforem na sklonku 18. století.

Dochované tituly z klášterní knihovny věrně odrážejí politické a kulturní zvraty v dějinách konventu. Pro starší období je patrná úzká vazba ženského konventu na mužský, kopírující zhruba obdobný stav v českokrumlovském dvojklášteru. Na prvním místě sledujeme rozvrstvení rukopisů na latinské a německé. ${ }^{66}$ Po provedené reformě se změnila skladba rukopisů (dominance jazykově německých rukopisů). Při jejich porovnání prakticky nemůžeme vycházet z poznatků jiných knihoven na území českých zemí, ale musíme se orientovat do německého prostředí a tamních reformovaných klášterů. $V$ př́padě tohoto kláštera je to především konvent v Norimberku. ${ }^{67}$ Sestry z norimberského konventu si s sebou evidentně přinesly korpus rukopisů, který byl následně doplňován a opisován v chebském prostř̌edí. Další rukopisy vznikaly v úzkém vztahu k těmto rukopisům a reagovaly na potřeby reformovaného konventu (Spruch geschrieben um Jesus, 14.-15. století, NK VII.G.19; Gebet nach der Beichte, 15. století, NK XIII.H.3m; Lebensregeln, Gebete, Traktate, 15. století, NK XVI.G.26; Tractatus ad musicae theoriam et alii textus, konec 15. století, NK XI.F.2; Leben der Heiligen - St. Brigitta, Katharina von Schweden und andere Werke, 2. polovina 15. století, NK XVI.F.1; Gebete und Traktate, 2. polovina 15. století, NK XVI.G.33. Bd.2; Gebete, 2. polovina 15. století, NK XVI.G.37; Gebetsbetrachtungen, 15./16. století, NK XVI.G.30a-c; Mystische Traktate, 15./16. století, NK XVI.G.31; Rosenkranz, Gebete, 15./16. století, NK XVI.G.33.Bd.1; Gebete, 15./16. století, NK XVI.G.18; Spiegel der Vollkommenheit der Minderbrüder, 15./16. století, NK XVI.E.15; Clarissinenregel, 1505, NK XVI.G.34; Gebetsbetrachtungen, 1511, NK XVI.G.20; Gebete und Betrachtungen, 1516, NK XVI.G.33. Bd.3; Humbertus de Romanis: Erklärung der Regel des hl. Augustin, 1517, NK XVI.D.18; Augustin Alvelder: Glosse über die Regel der Hl. Clara, 1535, NK XVI.E.20; Traktate von Meister Eckhart, Thomas von Kempen, Seusse, Holkot, 2. polovina 16. století, NK XVI.G.25; Augustin Alveder und Leben der hl. Clara, 1535, NK XVI.H.1. Vedle dochovaných liturgik (Breviarium, 15. století, NK VI.G.16a; breviarium, 15. sto-

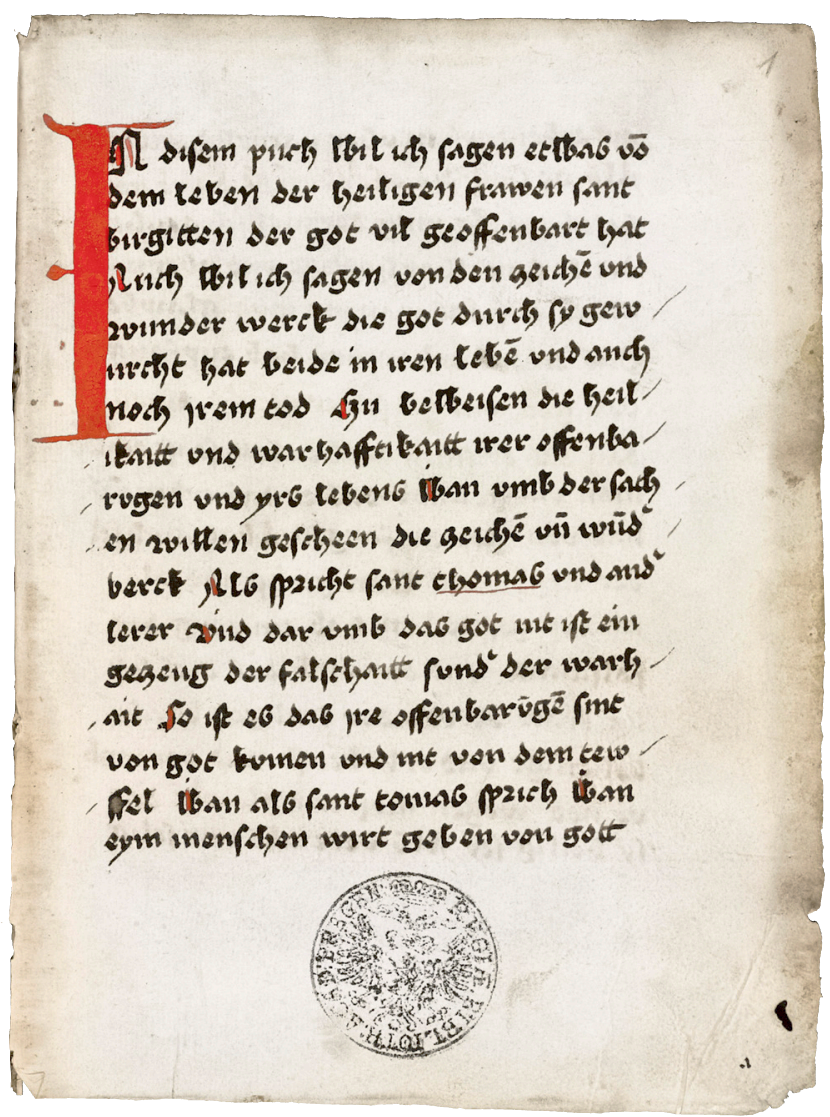

Obr. 8. Leben der Heiligen - St. Brigitta, Katharina von Schweden und andere Werke, Národní knihovna ČR, sign. XVI.F.1, fol. 1r. Foto: NK.

letí, NK VII.H.12; breviarium s německými komentáři, 15. století, NK XI.F.12; antiphonarium s německými př́ipisky, 15. století, NK XIV.G.51) je pro chebskou klášterní knihovnu vypovídajícím především větší množství mystických traktátů a devoční literatury. Vedle rukopisů se dochoval také běžný úřrední materiál. ${ }^{68} \mathrm{U}$ některých textů si nejsme zcela jistí jejich původem (norimberský, českokrumlovský nebo chebský konvent) ${ }^{69} \mathrm{~V}$ prrípadě mnohých rukopisů je patrné, že byly opisovány př́imo v chebském konventu sestrami pro vlastní potřebu a k soukromé četbě. ${ }^{70}$ Podoba těchto rukopisů je poměrně jednoduchá, prakticky postrádají složitou výzdobu. Po obsahové stránce je zajímavý především neobvykle zesílený výskyt mystických textů, orientujících se zejména do německého prostředí. Z tištěné produkce se dochovalo jen menší množství tisků (Das Buch Granatapfel Geilera von Kaysersberg vytištěno ve Štrasburku u Johanna Knoblocha v roce 1511 , Cheb 43/771; Io. Frob. Lectori S. D. In universas epistolas apostolorum ab ecclesia receptas Erasma Rotterdamského vytištěno v Basileji u Johanna Fro-

\footnotetext{
${ }^{66}$ Např́iklad Breviarium s německými komentáři, 14./15. století, NK VII.G.26.

${ }^{67}$ Ke konventu v Norimberku je četná literatura. Viz např́klad RENNER 1959; SCHNEIDER 1983; METSCHOLI 1987; HASEBRINK1996; BENNEWITZ 1997; WILLING 2004; STEINKE, 2006.

${ }^{68}$ Rủzné listy, počátek 16. století, NK XXIV.C.30; Brief der Felix Teuttin an die Äbtissin Seeburg im Stift S. Clara zu Eger, 16. století, NK XIV.G.51; Henigus Sele: Brief bei Übersendung der Statuten Papst Benedikts XII. von 1337 an die Clarissinen zu Eger, 1505, NK XVI.G.34.

${ }^{69}$ Nejistě (možná také Krumlov) Leben des hl. Franziskus und der hl. Agnes, 15. století, NK XVI.D.16; Mystische Traktate und Predigte, polovina 15. století, NK XVI.G.22; Das Buch des Gehorsams, 15. století, NK XVI.G.27; Gebetsbetrachtungen, 15./16. století, NK XVI.G.32.

${ }^{70}$ Pravděpodobně rukopis Meisterbuch, mystische Traktate und Predigte, druhá polovina 15. století, NK XVI.G.24 - uvedeny sestry Agnes Keisserin a Ursula Wickersteterin.

${ }^{71}$ VD16 G 721, VD16 G 750, VD16 G 753, VD16 G 756, VD16 G 804, VD16 G 812.
} 


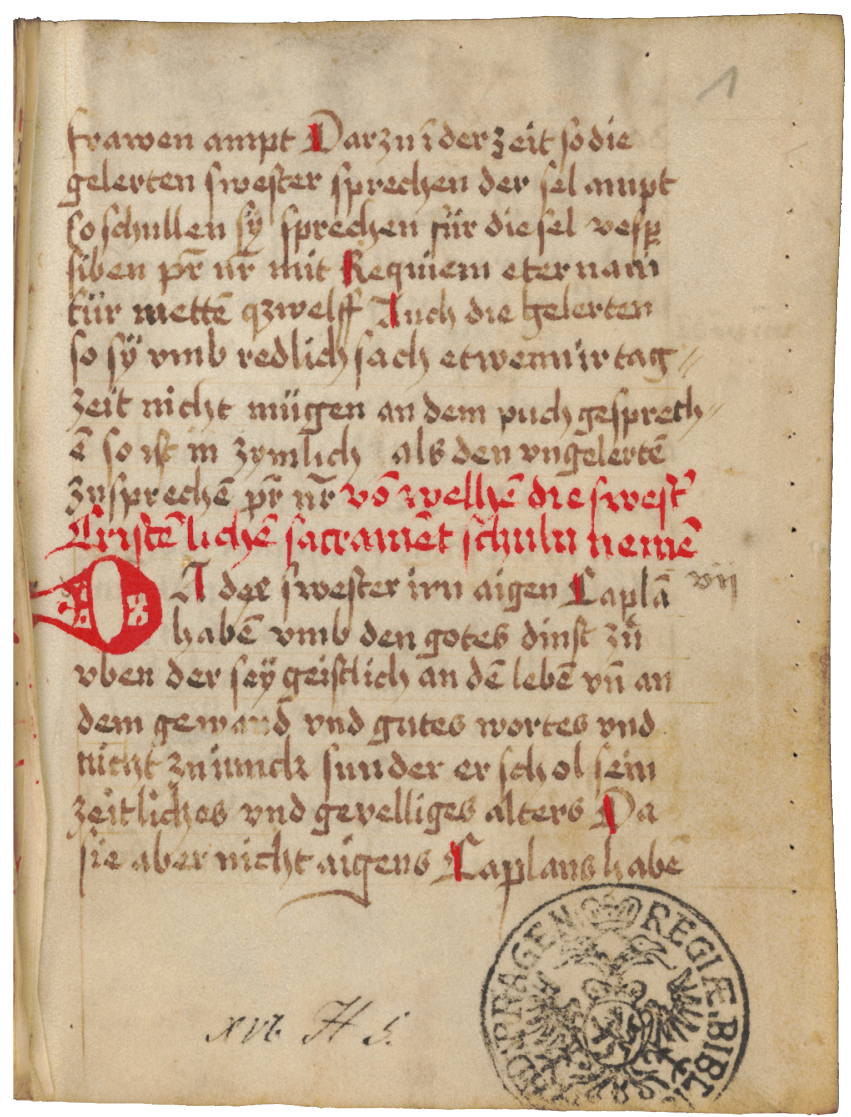

Obr. 9. Clarissinenregel, Národní knihovna ČR, sign. NK XVI.G.34, fol. 1r. Foto: NK.

bena v roce 1522 , Cheb 64/6072; darované vdovou Kateřinou v roce 1543 Rosarium Sermonum Bernardina Bustiho, vytištěno v Hagenau u Johanna Rynmana v roce 1508, Cheb $16 / 233 .{ }^{73}$

Chebská knihovna představuje modelový profil pozdně středověké knihovny reformovaného konventu. Na vzniku většiny rukopisů ve sledovaném období se prímo podílely samotné sestry, které si tak doplňovaly literaturu pro vlastní četbu. Vedle toho byly i nadále objednávány liturgické rukopisy, nutné pro chod kláštera a konventu. Naprostá dominance jazykově německých textů je dalším signifikantním znakem tohoto kláštera. Rapidní nárůst rukopisů v době krátce po reformě ukazuje, že každý zreformovaný konvent se vedle mnohého zaměřil na tvorbu vhodných textů. Tento model je snadno aplikovatelný i na ty konventy, u kterých tyto reformy jen tušíme a nemáme je pramenně podloženy. Právě výzkum jejich knihoven a dochovaných rukopisů při použití komparace naprríklad s tímto konventem by mohl být klíčový.

\section{Závěr}

Rozvoj knihovních korpusů ženských klášterů ve sledovaném období úměrně závisel na ekonomické, sociální a kulturní situaci konkrétního konventu. Kláštery mimo centrum husitských nepokojů a nezasažené válečnými událostmi (zejména klarisky v Českém Krumlově a Chebu, premonstrátky v Chotěšově) pokračovaly v plynulém přísunu kodexů. Navíc značnou roli hrála také př́ítomnost mužského kláštera, který se vedle péče o vlastní knihovnu mnohdy také staral o potřeby ženského kláštera (zejména $v$ př́ípadě premonstrátek v Chotěšově a klarisek v Českém Krumlově). $\mathrm{V}$ prrípadech Chebu a Chotěšova byly záhy v nemalé míře objednávány inkunábule jako nové, progresivní tištěné médium. Oproti tomu kláštery nacházející se v centru výše zmíněných událostí byly přímo odkázány na vnější poměry. Doplňování knihovny (benediktinky, snad dominikánky) probíhalo ve zpomaleném rytmu a pozornost nebyla vyhraněna ani na tištěné, ani na rukopisné médium. Kláštery, jejichž knihovny byly poničeny (snad př́ípad premonstrátek v Doksanech) musely primárně obnovit liturgika ve svých knihovnách. Napříč všemi knihovnami je patrná snaha o nákup nebo zhotovování titulů, které měly úzké vazby na soukromou liturgickou praxi sester (zesílené množství breviářo̊, antifonářù atd. v rukopisné i tištěné formě). Posílena byla především pozice devoční literatury (zejména $\mathrm{v}$ chebské knihovně). Jednotlivé rozdíly byly pak dány konkrétními specifiky kláštera. Mezi mnohými to byla zejména reforma a požadavek zcela nových titulů u klarisek v Chebu s jasnou orientací na jazykově německé prostředí, doplňování vzdělávací literatury a větší množství inkunábulí z německého a italského prostředí u premonstrátek v Chotěšově, související nejspíše s rozvinutým „citem“ pro knižní kulturu v mužském klášteru v Teplé. Je zjevné, že ženské konventy hluboce zaostávaly v počtu titulů za svými mužskými protějšky. Stejně tak skladba titulů byla mnohem méně pestrá. Ženské konventy ve sledovaném období (snad jen s hypotetickou výjimkou Chebu) rezignovaly na jakékoli snahy o formování kulturního ovzduší a spíše se zaměřily na vlastní sebevzdělávání a liturgickou praxi. Tím se výrazně vzdálily od soudobých ženských německých klášterů, které se v mnohém staly inspirátory kulturních proměn nebo alespoň adekvátně reagovaly na probíhající kulturní změny. V českém prostředí nebyla dostatečně stabilizovaná situace na to, aby jim byl rozmach tohoto typu umožněn.

\section{Příloha - soupis zkoumaných rukopisů a tisků}

Národní knihovna ČR, Oddělení rukopisů a starých tisků - rukopisy: Formula novitiam et Regula s. Benedicti, NK I.F.29; Psalterium I H 8 a; Psalterium I H 8 b; Necrologium monasterii ord. S. Clarae Crumloviensis, Martyrologium fr. min., NK VI.B.9; Breviarium NK VI.E.13; Breviarium NK VI.E.4c; Psalterium et hymnarius, NK VI.F.12c; Psalterium et hymnarius, NK VI.G.2; Corpus officiorum, NK VI.G.3a; Processionale, NK VI.G.3b; Processionale, NK VI.G.5; Processionale, NK VI.G.10a; Processionale, NK VI.G.10b; Breviarium, NK VI.G.11; Processionale, NK VI.G.15; Breviarium, NK VI.G.16a; Preces pro infirmis, NK VI.G.16b; Pseudo-Eusebius: Epistola ad Damasaum et David de Augusta: Speculum monacharum, NK VII.D.2; Antiphonarium perpetuis notis musicis instructum et usui ord. Prae-monstra-

\footnotetext{
${ }^{72}$ VD 16 E 3377.

${ }^{73}$ VD 16 B 1918.
} 
tensis adaptatum, NK VII.F.13; Breviarium, NK VII.F.23; Processionale, NK VII.G.7; Processionale, NK VII.G.16; Breviarium, NK VII.G.17d; Spruch geschrieben um Jesus, NK VII.G.19; Hymnarius, NK VII.H.1; Breviarium, NK VII.H.12; Breviarium, NK VII.H.15; David de Augusta: Knihy o životu duchovním nábožném a Knihy o sedmeru prospívání duchovníka, NK XI.C.6; Officia varia, Barlaam et Josafat, NK XI D 3; Tractatus ad musicae theoriam et alii textus, NK XI.F.2; Breviarium, NK XI.F.12; Antiphonarium, NK XII.A.17; Breviarium, NK XII.A.22; Bertrandus de Turre: Sermones super epistolas dominicales; Pantheon miraculorum, NK XII.D.6; Breviarium, NK XII.D.8a; Breviarium, NK XII.D.8b; Breviarium, NK XII.D.9; Dialogus beatae Mariae Virginis et Anselmi alii textus, NK XII.D.10; Preces, NK XII.D.11; Preces, NK XII.D.12; Pseucho-Prochorus: Acta sancti Johannis et alii textus, NK XII.D.13; Breviarium, NK XII.E.1; Processionale; NK XII.E.15a; Corpus officiorum, NK XII.E.15b; Hymnarius, NK XII.E.15c; Lectionarium NK XII.E.16; Breviarium, NK XII.F.5; Breviarium, NK XII.F.9; Rituale continens agenda circa infirmas et mortuas sorores, NK XII.F.14; Psalterium, NK XII.G.8; Psalterium, NK XII.G.11a; Breviarium, NK XII.G.20a; Psalterium, NK XII.G.20b; Lectionarium, NK XIII.A.1a; Lectionarium; XIII.A.1b; Fragmentum praebendarum, NK XIII.A.2; Breviarium, NK XIII.B.9; Breviarium, NK XIII.C.1a; Breviarium, NK XIII.C.1b; Antiphonarium, NK XIII.C.4; Breviarium, NK XIII.C.5; Antiphonarium, NK XIII.C.7; Psalterium, NK XIII.D.18; Breviarium, NK XIII.E.1; Breviarium, NK XIII.E.14a; Psalterium, NK XIII.E.14b; Bernardus Claraevallensis: Sermo CIV, Bonaventura: Lignum vitae et alii textus, NK XIII.E.14c; Liber ordinarius, NK XIII.E.14d; Breviarium, NK XIII.E.14e; Breviarium, NK XIII.E.14f; Martyrologium cum necrologio, NK XIII.G.20; Processionale, NK XIII.H.3c; Gebet nach der Beichte, NK XIII.H.3m; Breviarium, NK XIII.H.3.r; Quod dicitur Passionale abbatissae Cunegundis, NK XIV.A.17; Antiphonarium, NK XIV.B.13; Misál chotěšovského kláštera, NK XIV.C.3; Martyrologium praecedente Necrologio monasterii s. Annae Vetero-Prag, NK XIV.C.10; Antiphonarium, NK XIV.C.20; Expositiones super Ave Maria, NK XIV.D.13; Processionale NK XIV.D.21; Opera varia, NK XIV.E.10; Breviarium ordinis Praemonstratensis (?) cum benedictionibus et aliis additamentis, NK XIV.E.15; Breviarium, NK XIV.F.12; Corpus officiorum, NK XIV.G.46; Antiphonarium, NK XIV.G.51; Deutsche Glossen in S. Bernhards Tractat, NK XIV.H.26; Urbář kláštera Chotěšovského, NK XV.A.4; Registrum censuum et proventuum monasterii Chotěšoviensis, NK XV.A.5; Meister Heinrichs Predigt, NK XVI.A.2; Leben des hl. Franziskus und der hl. Agnes, NK XVI.D.16; Humbertus de Romanis: Erklärung der Regel des hl. Augustin, NK XVI.D.18; Mystické traktáty, NK XVI.E.14; Spiegel der Vollkommenheit der Minderbrüder, NK XVI.E.15; Augustin Alvelder: Glosse über die Regel der Hl. Clara, NK XVI.E.20; Leben der Heiligen - St. Brigitta, Katharina von Schweden und andere Werke, NK XVI.F.1; Gebete, NK XVI.G.18; Gebetsbetrachtungen, NK XVI.G.20; Mystische Traktate und Predigte, polovina 15. století, NK XVI.G.22; Traktate von Meister Eckhart, Thomas von Kempen, Seusse, Holkot, NK XVI.G.25; Das Buch des Gehorsams, NK XVI.G.27;
Lebensregeln, Gebete, Traktate, NK XVI.G.26; Gebetsbetrachtungen, NK XVI.G.30a-c; Latinské hodinky chotěšovské panny Johanky, NK XVI.G.31; Gebetsbetrachtungen, NK XVI.G.32; Rosenkranz, Gebete, NK XVI.G.33.Bd.1; Gebete und Traktate, NK XVI.G.33.Bd.2; Gebete und Betrachtungen, NK XVI.G.33. Bd.3; Clarissinenregel, NK XVI.G.34; Gebete, NK XVI.G.37; Augustin Alveder und Leben der hl. Clara, NK XVI.H.1; Donat, český překlad magdeburské, po př́padě saské městské právní knihy zvané Weichbildvulgata, 1547, NK XVII.C.24; O svatém Jeronýmovi knihy troje a Povídka o Tobiášovi, NK XVII.E.9; Notule od kněze Jiř́ika, NK XVII.E.20; Žaltář s kantikami, NK XVII.F.8; Řehole upravená pro potřeby jeptišek, NK XVII.F.14; Hodinky, NK XVII.G.3; Život blahoslavené Panny Kateřiny Senenské, NK XVII.H.8; Texty sv. Jana Zlatoústého, sv. Cypriana v překladu Viktorina ze Všehrd, a sv. Anselma, NK XVII.H.11; Žaltář, písařem Šimon, kaplan Petrlíkovský, NK XVII.J.6; Klementinská legenda o sv. Jiř́i, NK XVII.J.17/11; Breviarium, NK XXIII.D.138; Breviarium, NK XXIII.D.142; Breviarium, NK XXIII.D.155; Breviarium, NK XXIII.D.156; Různé listy, NK XXIV.C.30; Vita fratris Hroznatae, Teplensis et Chotiessowiensis monasterii fundatoris, Teplá MS.b.1; Breviarium, Teplá MS. b 13; Responsorium, 1482, Teplá MS. b 18; Agenda monasterii Chotiessoviensis, Teplá MS. D 4

- inkunábule: Sermones de tempore et de sanctis, sive Hortulus reginae Meffretha, Basel: Nicolaus Kestler, 1483, Teplá D 2; Psalterium. Leipzig: Mauritius Brandis, 30.3.1485, Teplá B 40; Breviarium praemonstratense. Alost: Theodoric Martin, 1488, Teplá B 91; Bertholdus: Zeiglöcklein des Lebens und Leidens Christi. Nürnberg: Friedrich Creussner, 11. 5. 1489, Teplá A 19; Albumasara Introductorium in astronomiam, Augsburg: Erhard Ratdolt, 1489, Teplá B 43

- tisky: Olivier Mailland: Sermones de adventu. Strassbourg: Johann Knobloch, 1506, NK 34 D 254; Petrus Lombardiensis: Quattuor sententiarum volumina. Venetia: Lazarus Soardus, 23. 3. 1507, NK Teplá B 134; Bernardino Busti: Rosarium Sermonum, Hagenau: Johann Rynmann 1508, Cheb 16/233; Johann Herolt: Discipulus de eruditione chrisfidelium compendiosus. Strasbourg: Martin Flach, 1509, Teplá C 115; Marcus Valerius Probus: Interpretamenta litterarum. Oppenheim: Köbel, 1510, NK 6 H 26; Geiler von Kayserberg. Strassbourg: Johann Knobloch, 1511, Cheb 43/7; Hieronymus Brunschwig: Liber de arte Distillandi de Compositis. Straßburg: Grüninger, Johann, 1512, NK 18 A 134; Pietro Natali: Catalogus sanctorum et gestorum eorum ex diversis voluminibus collectus, Lyon: Jacque Saccon, 9.12.1514, Teplá D 81; Hortulus anime. Zahradka dusse. Nürnberg: Hieronymus Höltzel, 1520, NK 54.F.256; Erasmus Rotterodamensis: Io. Frobenius Studiorum Liberalium Mystis. Basel: Johannes Froben, 1520, NK 8 B 71; Erasmus Rotterodamensis: Io. Frob. Lectori S. D. In universas epistolas apostolorum ab ecclesia receptas. Basel: Johann Froben, 1522, Cheb 64/60; Eusebius de Caesarea: Autores historiae ecclesiasticae. Basel: Johannes Froben, 1523, NK 21 B 70, NK Sb 39; Conrad von Halberstadt: Concordantiae maiores sacrae scripturae. Strassbourg: Georg Ulrich, 1529, Teplá E 98; Miscellanearum libri duo Friedricha Nausea. Köln am Rhein: Peter Quentell, 1531, Teplá B 200; Augustinus 
Aurelius. Pobožné dwoge Kázanij Swatého Augustyna času Adwentnijho w Cžeský Jazyk přeložené a k naučenij y k potěssenij wěrných Dussý Křestianských wydané...s.l.: 1567, NK 54.E.59

Národní muzeum, Knihovna Národního muzea - rukopisy: Žaltář, KNM III H 64; Breviarium, KNM XIV.D.13; Psalterium, KNM XVI.A.18

- inkunábule: Crescenzi, Pietro de. Ruralia commoda. Strasbourg: Jordani de Quedlinburg, 9.III.1486, Křivoklát 22 d 25

- tisky: Hortulus anime. Zahradka dusse. Nürnberg: Hieronymus Höltzel, KNM 25.F.8; Augustinus Aurelius. Pobožné dwoge Kázanij Swatého Augustyna času Adwentnijho w Č̌eský Jazyk přeložené a k naučenij y k potěssenij wěrných Dussý Křestianských wydané...s.1.: 1567, KNM 36.A.2

Královská kanonie premonstrátů na Strahově

- České modlitby, Strahov DCV 24

- neidentifikované inkunábule: Sermones dominicales cum expositionibus Evangeliorum, nuncupati Dormi secure; Sermones de Sanctis, Basileae 1482; Lyra, Nicol de: Postillae super librum Psalmorum Pariis 1483 [Nicolaus de Lyra: Postilla super Psalterium. Paris: Ulrich Gering, 5.11.1483]; Janua, Joannes de: Summa quae vocatur Catholicon, Norimbergae 1483; Tractatus de arte et vero modo praedicandi, Memingae 1483; Voragine Sermones de sanctis, Augustae 1484; Comestor, Petrus: Scholastica historia S. Scripturae seriem exponens Argentinae 1485; Passional das ist Leben der heiligen... Augsburg 1485 (nejspíše Jacobus de Voragine: Legenda aurea sanctorum, sive Lombardica historia [German] Leben der Heiligen: Winterteil (I) und Sommerteil (II). Augsburg: [Johann Schönsperger], 1485); Historia Lombardica seu Legenda Sanctorum, Argentinae 1486; Sermones de Sanctis per annum Dormi secure nuncupati, Argentinae 1488; Missale Pragense. Bamberg: [Johann Sensenschmidt et Heinrich Petzensteiner], 1489; Postilla super Evangelia Dominicalia, et de Sanctis secundum sensum literalem collecta. Argentinae 1489; Valerii Probi et Pomponii Laeti Opuscula, Argentorati apud Schurerum, 1510; Vincentii S. Sermonum de tempore pars aestivalis, Argentinae 1489 [Ferrerius, Vincentius S.:Sermones de tempore et de sanctis. Strassburg: Georg Husner, 1488-1489]; Concordantia discordantium. S.1. 1489; Historia Lombardica seu Legenda Sanctorum, Argentinae 1490; Alexandri Glossa Primae et Secundae partis cum notabilibus et argumentis quibusdam Lipsiae apud Conr. Kacheloven, 1491 [pravděpodobně Alexander de Villa Dei: Doctrinale Pars I. Leipzig: Conrad Kachelofen, 1491]; Vocabularius praedicantium, Lipsiae per Conradum Kachelowen, 1491; Dorme secure seu Sermones de tempore, Argentinae 1493 [Johannes de Verdena: Sermones „Dormi secure“ de tempore et de sanctis, Strassburg: Georg Husner, 1493-94]; Eiusdem item tertia et quarta pars doctrinalis ibidem ad eodem [pravděpodobně Alexander de Villa Dei: Doctrinale Partes III et IV. Leipzig: Conrad Kachelofen, cca 1491]; Solinus de Mirabilibus mundi, Venetiis 1491; Lavacrum conscientiae omnium sacerdotum, Augsburg 1492; Anima fidelis seu opus super epistolas totius quadragesimae. Lugduni per Joann. De Vingle 1494; Sermones de Sanctis perutiles a quodam fratri Hungariae Ordinis minorum Biga Salutis intitulati, Hagenaw 1494; Lochmayr, Michal: Sermones de Sanctis, Haganoae 1494; Gritschii, Joan.: Quadragesimale 1495; Passional bohemice Pragae 1495; Antonii Summa Confessionis Venetiis 1495; Guillermus: Postilla super epistolas et evangelia totius anni. Augustae 1495 [Guillermus: Postilla super epistolas et evangelia. Strassburg: Johann Prüss, cca 1495]; Passional neb Ziwot a Umuczenij wssech swatych Muczedtnikuw w Praze 1495; Philethi, Franc.: Epistolae, Basileae 1495; Pomponii, Laeti: De Romanorum Magistratibus, Sacerdotibus, Jurisperitis et Legibus ad M. Pantagotum Libellus. Bononiae 1495; Utino, Leonardo de: Sermones aurei de Sanctis, Lugduni 1495; Vocabularius breviloquiae utriusque Iuris, Argentinae 1495; Passionale i. e. Žiwot a Umuczeni wssech Swatych Muczedlnikuw w Praze 1495; Jacobi Januensis Legenda Sanctorum quae Lombardica nominatim historia, Argentinae 1496; Michaelis Medolanensis Sermonarium de poenitentia, Venetiis 1496; Corvini, Lauri: Cosmographiae dans manuductionem in tabulas Ptolemaii ostendens omnes regiones, terrae, habitabiles diversa hominum genera diversis moribus et conditionibus viventes, annumerans diversae animaliae 1496; Sabunde, Raymundus de: Theologia naturalis, Argentinae per Mart. Flach 1496; Lochmayr, Michael: Sermones de sanctis, Haganoae 1497; Wann, Paulus: Sermones de tempore, Hagenoae 1497; Missale emendatum juxta rubricam Pragensis Ecclesiae [Missale Pragense] Leipzig: Conrad Kachelofen, 1498; Lombardi Petri: Textus Sententiarum cum conclusionibus M. Henrici Gorchen, Basileae 1498 [Petrus Lombardus: Sententiarum libri IV. Comm: Henricus de Gorichem. Add: Articuli in Aglia et Parisiis condemnati. Basel: Nicolaus Kessler, 20.2.1498]; Biga Salutis sive Sermones Dominicales, Haganaoae 1498; Kniha Chwal Bozskych, s.l. 1499; Wann, Paulus: Sermones de tempore, Hagenoae 1497 (ISTC iw00006000); Wann, Paulus: Sermones de tempore, Hagenoae 1499; Pelbarti Pars aestivalis Sermonum de Sanctis. Hagenaw 1499; Statuta Praemonstratensis, s.1. 1500

- neidentifikované tisky: Pelbarti Sermones Pomerii de Sanctis, 1501; Coelifodina et Epistolae quaedam. Erfordiae per Wolfg. Scheuker 1502; Breviarium Horarum Canonicarum Secundum Rubricam Ecclesiae Archiepisc. Pragens. Impensis Georgii Furchs de Sultzpach. Nürnbergae 1502; Biga Salutis sive Sermones de Sanctis Haganaoae 1502 [Lasko, Osvald: Sermones de sanctis, Hagenau: Heinrich Gran; Augsburg: Johann Rynman, 1502]; Bartolus de Saxoferrato: Modus legendi Abbreviaturas in utroque iure, Argentinae 1504; Pelbarti Sermones de tempore 1508; Žaltarz y mnoho gyne pysniczky proroczke w Plzni u Mikulase Bakalarze 1508; Passional genannt das Leben der heiligen Transl. Strassburg durch Johann Grüninger 1510; Pelbarti de Temesvar De observantiae, Hagenaw 1511; Antonii Summa; Bernecker, Johann Adam: Album Augustissimae Domus Habspurgico-Austriacae, Pragae apud Wolfgang Wikhart 1513; Aristotelis Stagiritae Philosophorum maxime oeconomicorum libri duo translati egraece in latinum a Leonardo Arethino Liptzig 1511; Pauli D. Epistolae quatuordecim juxta D. Hieronymo translationem Liptzig 1514; Psalterium 
Davidis per D. Auretium August. In tres quinquaegenas divisum Liptzig. 1514; Psalterius Davidis cum hymnis, Leipstik, 1514; Breviarium Venetiis per Jac. Mentium de Leuco, 1518; Czteni a Epistoly Nedělni... Praha, 1527

\section{Prameny:}

Archiv Národní knihovny ČR, VKU, č. kartonu 84 (benediktinky u sv. Jiří).

Národní archiv v Praze, fond Česká státní účtárna, inv. č. 2056, karton č. 323 .

\section{Literatura:}

ACHTEN 1980: ACHTEN, Gerard. Das christliche Gebetbuch im Mittelalter. Andachts- und Stundenbücher in Handschrift unf Früdruck. Ausstellungskatalog der Staatsbibliothek - Preussischer Kulturbesitz, Berlin. Staatsbilbiothek Preussischer Kulturbesitz Berlin 1980. Wiesbaden: Reichtert, 1980.

BABCOCK 1993: BABCOCK, Robert G. Reconstructing a Medieval Library. New Haven: Beinecke Rare Book and Manuscript Library, 1993.

BARTOŠ 1926: BARTOŠ, František Michálek. Soupis rukopisů Národního musea v Praze. Svazek I-II. V Praze: Melantrich, 1926.

BASTL 2004: BASTL, Ondřej. Knihy a listiny zrušeného svatojiřského kláštera. In: Seminář a jeho hosté. II. Sborník př́spěvků k nedožitým 70. narozeninám doc. dr. Rostislava Nového. Praha: Scriptorium, 2004, s. 187-223.

BELL 1995: BELL, David N. What Nuns Read: Books and Libraries in Medieval English Nunneries. Cistercian Studies Series 158. Kalamazoo: Cistercian Publications, 1995.

BENEŠ et al. 2015: BENEŠ, Jiří et al. Rukopisné zlomky Knihovny Národního muzea: signatury 1 B a 1 C. Praha: Národní muzeum, Scriptorium, 2015.

BENNEWITZ 1997: BENNEWITZ, Nadia. Weibliche Lebensformen im Mittelalter. Beginen und Seelfrauen in der Reichsstadt Nürnberg. Eine Dokumentation über die religiöse Frauenbewegung des Mittelalters unter besonderer Berücksichtigung der Nürnberger Verhältnisse. Nürnberg: Studienzentrum Heilig Geist, 1997.

BLANTON - O'MARA - STOOP 2013: BLANTON, Virginia - O'MARA, Veronica - STOOP, Patricia. Nuns' Literacies in Medieval Europe: The Hull Dialogue. Medieval Women: Texts and Context 26. Turnhout: Brepols, 2013.

BOLDAN 2018: BOLDAN, Kamil. Počátky českého knihtisku. Praha: Scriptorium, 2018.

BRČÁK et al. 2014: BRČÁK, Marek et al. Rukopisné zlomky Knihovny Národního muzea: signatura 1 A. V Praze: Národní muzeum, Scriptorium, 2014

BROM et al. 2016: BROM, Vlastimil et al. Rukopisné zlomky Knihovny Národního muzea: signatury 1 D, 1 E a 1 G. Praha: Národní muzeum, Scriptorium, 2016.

CARMASSI - SCHLOTHEUBER - BREITENBACH 2014: CARMASSI, Patrizia - SCHLOTHEUBER, Eva BREITENBACH, Almut. Schriftkultur und religiöse Zentren im norddeutschen Raum. Wiesbaden: Harrassowitz 2014.
DOLCH 1909: DOLCH, Walther. Katalog der deutschen Handschriften der K. K. Öff. und Universitätsbibliothek zu Prag. I. Teil. Die Handschriften bis etwa z. J. 1550. Prag, Calve, 1909

DRAGOUN 2011: DRAGOUN, Michal. Soupis středověkých rukopisů Knihovny Národního muzea: doplňky ke katalogům F.M. Bartoše, J. Vašici a J. Vajse. Praha: Národní muzeum, Scriptorium, 2011.

DRAGOUN 2017: DRAGOUN, Michal. Rukopisné zlomky Knihovny Národního muzea: signatura $1 \mathrm{~K}$. Dodatky ke sbirkám Adolfa Patery a Čeňka Zíbrta. Praha: Národní muzeum, Scriptorium, 2017

DRAGOUN - MAREK 2012: DRAGOUN, Michal - MAREK, Jindřich. Rukopisné zlomky Knihovny Národního muzea: sbirky Adolfa Patery a Čeňka Zíbrta. Praha: Národní muzeum, Scriptorium, 2012.

EHRENSCHWEDTNER 2004: EHRENSCHWEDTNER, Marie-Luise. Die Bildung der Dominikanerinnen in Süddeutschland vom 13. bis 15. Jahrhundert. Stuttgart: Steiner, 2004.

EISERMANN - SCHLOTHEUBER - HONEMANN 2004: EISERMANN, Falk - SCHLOTHEUBER, Eva HONEMANN, Volker. Studien und Texte zur literarischen und materiellen Kultur der Frauenklöster im späten Mittelalter: Ergebnisse eines Arbeitsgesprächs in der Herzog August Bibliothek Wolfenbüttel, 24.-26. Febr. 1999. Leiden: Brill, 2004.

EMBACH - RAPP 2008: EMBACH, Michael - RAPP, Andrea. Rekonstruktion und Erschliessung mittelalterlicher Bibliotheken: neue Formen der Handschriftenpräsentation. Berlin: Akademie Verlag, 2008.

ERLER 2002: ERLER, Mary. Women, Reading and Piety in Late Medieval England. Cambridge: Cambridge University Press, 2002.

HAMBURGER 1997: HAMBURGER, Jeffrey F. Nuns as Artists: The Visual Culture of a Medieval Convent. Berkeley: University of California Press, 1997.

HAMBURGER 1998: HAMBURGER, Jeffrey F. The Visual and the Visionary. Art and Female Spirituality in Late Medieval Germany. New York: Zone Books, 1998.

HAMBURGER - JÄGGI - MARTI - RÖCKELEIN 2007: HAMBURGER, Jeffrey F. - JÄGGI, Carola - MARTI, Susan - RÖCKELEIN, Hedwig. Frauen - Kloster Kunst. Neue Forschungen zur Kulturgeschichte des Mittelalters. Beiträge zum Internationalen Kolloquium vom 13.-16. Mai 2005 in Mülheim/Ruhr, anläßlich der Ausstellung ,,Krone und Schleier. Kunst aus mittelalterlichen Frauenklöstem " in der Bundesausstellungshalle Bonn und im Ruhrlandmuseum Essen. Turnhout: Brepols, 2007.

HAMBURGER - MARTI 2008: HAMBURGER, Jeffrey F. - MARTI, Susan. Crown and Veil: Female Monasticism from the fifth to the fifteenth centuries. New York: Columbia University Press, 2008.

HASEBRINK 1996: HASEBRINK, Burkhard. Tischlesung und Bildungskultur im Nürnberger Katharinenkloster I. Beitrag zu ihrer Rekonstruktion. In: KINTZINGER, Martin (ed.) Schule und Schüler im Mittelalter: Beiträge zur europäischen Bildungsgeschichte des 9. bis 15. Jahrhunderts. Köln: Böhlau, 1996, s. 187-216. 
HLAVÁČEK 2005: HLAVÁČEK, Ivan. Knihy a knihovny v českém středověku. Praha: Karolinum, 2005.

HLINOMAZ 2000: HLINOMAZ, Milan. Přehled tepelských prvotisků: Incunabula quae in Bibliotheca Teplensis asservantus. Památce dr. Waltera Dolcha. Minulostí západočeské kraje 35, 2000, s. 167-243.

HLINOMAZ 2001: HLINOMAZ, Milan. Postinkunábule a paleotypy v knihovně kláštera premonstrátů Teplá. Minulostí Západočeské kraje 36, 2001, s. 147-253.

HLINOMAZ 2009: HLINOMAZ, Milan. Dějiny kláštera premonstrátek $v$ Chotěšově. České Budějovice: Veduta, 2009.

HOFFMANN 1999: HOFFMANN, František. Soupis rukopisů knihovny Kláštera premonstrátů Teplá. I-II. Praha: Archiv akademie věd ČR, 1999.

HRADILOVÁ 2014: HRADILOVÁ, Marta. $K$ dějinám knihovny minoritů v Českém Krumlově. Praha: Scriptorium, Masarykův ústav a Archiv Akademie věd ČR, 2014.

GRASSL 1931: GRASSL, Basil. Das älteste Totenbuch des Praemonstratenser-Chorfrauenstiftes Chotieschau (12001640). Tongerloo: Abtei, 1931. Analecta Praemonstratensia 7.

JÄGGI 2006: JÄGGI, Carola. Frauenklöster im Spätmittelalter. Die Kirchen der Klarissen und Dominikanerinnen im 13. und 14. Jahrhundert. Petersberg: Michael Imhof, 2006. KRUSE 2013: KRUSE, Britta-Juliane. Rosenkränze und Seelengärten: Bildung und Frömmigkeit in niedersächsischen Frauenklöstern. Wiesbaden: Harrassowitz, 2013.

MAREK - DRAGOUN 2016: MAREK, Jindřich - DRAGOUN, Michal. Soupis středověkých latinských rukopisů Národní knihovny ČR: doplňky ke katalogu Josefa Truhlá$\check{r}$ e = Catalogus codicum manu scriptorum Latinorum medii aevi qui in Bibliotheca Nationali olim Universitatis Pragensis asservantur: additamenta ad catalogum Josephi Truhlár. Praha: Národní knihovna České republiky, 2016.

MAREK - MODRÁKOVÁ 2006: MAREK, Jindřich - MODRÁKOVÁ, Renáta. Zlomky rukopisů v Národní knihovně České republiky. Praha: Národní knihovna České republiky, 2006.

MENGIS 2013: MENGIS, Simone. Schreibende Frauen um 1500: Scriptorium und Bibliothek des Dominikanerinnenklosters St. Katharina St. Gallen. Berlin: De Gruyter, 2013.

METSCHOLI 1987: METSCHOLI, Ingrid. Der Bibliotheksbestand des St. Katharinenklosters in Nürnberg vor der Klosterreform 1428, München 1987 (nepublikovaná magisterská práce).

MIKA 1726: MIKA, Joseph. Dar Ruhmwürdige Doxan, Oder: Des königl. Jungfräulichen Stiffts, Der Schneeweissen Hochbefreyten Praemonstratenser Jungfrauen zu Doxan. Leitmeritz: Schkrochowsky 1726.

MODRÁKOVÁ 2015: MODRÁKOVÁ, Renáta. Středověké rukopisy v soukromém vlastnictví benediktinek z kláštera sv. Jiří na Pražském hradě. In: RADIMSKÁ, Jitka (ed.). Knihy v proměnách času. Opera romanica 16. České Budějovice: Jihočeská univerzita v Českých Budějovicích, 2015, s. 337-354.

MODRÁKOVÁ 2016: MODRÁKOVÁ, Renáta. Ego indigna et misera famula tua. In: KLIMEK, Tomáš - MODRÁKOVÁ, Renáta (edd.). Cesta $k$ rozmanitosti, aneb, Ka- várenský povaleč digitálním historikem středověku: sborník př́spěvků k životnímu jubileu PhDr. Zdeňka Uhlíre. Praha: Národní knihovna České republiky, 2016, s. 177-189.

MODRÁKOVA 2019: MODRÁKOVÁ, Renáta. The Change of Historical Periods in the Light of Manuscripts and their Scribes from the Benedictine St. George's Convent at the Prague Castle at the Beginning of the 14th Century. In: OVERGAAUW, Eew - SCHUBERT, Martin (edd.). Change in medieval and Renaissance scripts and manuscripts. Proceedings of the19th Colloque international de paléographie latine (Berlin, Staatsbibliothek zu Berlin on September 16.18. 2015. Turnhout: Brepols, 2019.

MULDER-BAKKER 2004: MULDER-BAKKER, Anneke B. Seeing and Knowing. Women and Learning in Medieval Europe 1200-1550. Turnhout: Brepols, 2004.

PARISSE 2007: PARISSE, Michel. Les nonnes au Moyen Age. Le Puy: Christine Bonneton, 1983.

PLOCEK 1973: PLOCEK, Václav. Catalogus codicum notis musicis instructorum...qui in Bibliotheca universitatis Pragensis servantur. I-II. Pragae: Academia, 1973.

POWER 1922: POWER, Eileen. Medieval English Nunneries c. 1275 to 1535. Cambridge: Cambridge University Press, 2012.

RENEVEY - WHITEHEAD 2000: RENEVEY, Denis WHITEHEAD, Christiania. Writing religious women. Female Spiritual and Textual Practices in Late Medieval England. Toronto: University of Toronto Press, 2000.

RENNER 1959: RENNER, Peter. Spätmittelalterliche Klosterpredigten aus Nürnberg. Archiv für Kulturgeschichte 41, 1959, s. 201-217.

RÜCK - BOGHARDT 1994: RÜCK, Peter - BOGHARDT, Martin. Rationalisierung der Buchherstellung im Mittelalters und in der frühen Neuzeit, Ergebnisse eines buchgeschichtlichen Seminar. Wolfenbüttel 12.-14. Nov. 1990. Marburg: Institut für Historische Hilfswissenschaften, 1994.

SCHLOTHEUBER 2004: SCHLOTHEUBER, Eva. Klostereintritt und Bildung. Die Lebenswelt der Nonnen im späten Mittelalter. Mit einer Edition des Konventsgebuchs einer Zisterzienserin von Heilig-Kreuz bei Braunschweig, 14841507. Tübingen: Mohr Siebeck Verlag 2004.

SCHNEIDER 1983: SCHNEIDER, Karin. Die Bibliothek des Katharinenklosters in Nürnberg und die städtische Gesellschaft. In: MOELLER, Bernd - PATZE, Hans - STACKMANN, Karl (edd.). Studien zum städtischen Bildungswesen des späten Mittelalters und der frühen Neuzeit. Bericht über Kolloquien der Kommission zur Erforschung der Kultur des Spätmittelalters 1979-1981. Göttingen 1983, s. 70-82.

SIGNORI 2000: SIGNORI, Gabriela. Lesen, Schreiben, Sticken und Erinnern. Beiträge zur Kultur- und Sozialgeschichte mittelalterlicher Frauenklöster. Bielefeld: Verlag für Regionalgeschichte, 2000.

STEINKE 2006: STEINKE, Barbara. Paradiesgarten oder Gefängnis? Das Nürnberger Katharinenkloster zwischen Klosterreform und Reformation. Tübingen: Mohr Siebeck, 2006.

STUDNIČKOVÁ - BOLDAN - MODRÁKOVÁ 2019: STUDNIČKOVÁ, Milada - BOLDAN, Kamil - MODRÁ- 
KOVÁ, Renáta. Nebeský žebřik. Pozdně stredověké knihy ze sbirek Národní knihovny ČR. Praha: Scriptorium 2019.

TRUHLÁř 1905-1906: TRUHLÁR̆, Josef. Catalogus codicum manu scriptorum latinorum qui in c. c. Bibliotheca publica atque universitatis Pragensis asservantur. I-II. Pragae: Regia societas scientiarum Bohemica, 1905-1906.

TRUHLÁŘ 1906: TRUHLÁŘ, Josef. Katalog českých rukopisů c. k. veřejné a universitní knihovny pražské. Praha: Česká akademie císaře Františka Josefa pro vědy, slovesnost a umění, 1906.

WATT 2007: WATT, Diane. Medieval women's writing: works by and for women in England $1100-1500$. Cambridge: Polity Press, 2007.

WILLING 2004: WILLING, Antje. Literatur und Ordensreform im 15. Jahrhundert. Deutsche Abendmahlsschriften im Nürnberger Katharinenkloster. Münster: Weizmann, 2004. Studien und Texte zum Mittelalter und zur frühen Neuzeit 4.

\section{Internetové zdroje:}

Manuscriptorium - Digitální knihovna [online]. Národní knihovna České republiky. [Cit. 4. 10. 2010]. Dostupné z: www.manuscriptorium.com
KPS-Databáze Knihopis [online]. Národní knihovna České republiky. [Cit. 4. 10. 2010]. Dostupné z: www.knihopis.cz PROVENIO - Virtuální rekonstrukce knižních celkủ [online]. Knihovna Národního muzea. [Cit. 4.10.2010]. Dostupné z https://www.provenio.net/.

ISTC - Incunabula Short Title Catalogue [online]. The British Library. [Cit. 4. 10. 2010]. Dostupné z: https://data.cerl. org/istc/_search

VD 16 - Das Verzeichnis der im deutschen Sprachbereich erschienenen Drucke des 16. Jahrhunderts [online]. Bayerische StaatsBibliothek. [Cit. 4.10.2010]. Dostupné z: https://www.bsb-muenchen.de/sammlungen/historische-drucke/recherche/vd-16/

$G W-$ Gesamtkatalog der Wiegendrucke [online]. Staatsbibliothek zu Berlin. [Cit. 4.10.2010]. Dostupné z: https:// www.gesamtkatalogderwiegendrucke.del

\section{Renáta Modráková}

oddělení rukopisů a starých tisků Národní knihovna České republiky

Klementinum 190

11001 Praha 1 